\title{
Article \\ Effect of Foliar Supplied PGRs on Flower Growth and Antioxidant Activity of African Marigold (Tagetes erecta L.)
}

\author{
Sadia Sadique ${ }^{1,+}$, Muhammad Moaaz Ali ${ }^{2,3,+}{ }^{\mathbb{D}}$, Muhammad Usman ${ }^{4}$ (D), Mahmood Ul Hasan ${ }^{3}$, \\ Ahmed F. Yousef ${ }^{2,5}$, Muhammad Adnan ${ }^{6}\left(\mathbb{D}\right.$, Shaista Gull ${ }^{3,7}$ and Silvana Nicola ${ }^{8, *(D)}$
}

1 Department of Chemistry, University of Agriculture, Faisalabad 38000, Pakistan; sadiajee81@gmail.com

2 College of Horticulture, Fujian Agriculture and Forestry University, Fuzhou 350002, China; muhammadmoaazali@yahoo.com (M.M.A.); ahmedfathy201161@yahoo.com (A.F.Y.)

3 Institute of Horticultural Sciences, University of Agriculture, Faisalabad 38040, Pakistan; mahmoodulhassan1947@gmail.com (M.U.H.); shaistagull205@gmail.com (S.G.)

4 Institute of Soil and Environmental Science, University of Agriculture, Faisalabad 38040, Pakistan; usmansomi90@gmail.com

5 Department of Horticulture, College of Agriculture, University of Al-Azhar (Branch Assiut), Assiut 71524, Egypt

6 Department of Agronomy, College of Agriculture, University of Sargodha, Sargodha 40100, Pakistan; mughal3368@gmail.com

7 Department of Horticulture, Bahauddin Zakariya University, Multan 66000, Pakistan

8 Department of Agricultural, Forest, and Food Sciences-DISAFA, Horticultural

Sciences-INHORTOSANITAS, University of Torino, 10095 Grugliasco, Italy

* Correspondence: silvana.nicola@unito.it

+ Equally contributed authors.

Citation: Sadique, S.; Ali, M.M.; Usman, M.; Hasan, M.U.; Yousef, A.F.; Adnan, M.; Gull, S.; Nicola, S. Effect of Foliar Supplied PGRs on Flower Growth and Antioxidant Activity of African Marigold (Tagetes erecta L.). Horticulturae 2021, 7, 378. https:// doi.org/10.3390/horticulturae7100378

Academic Editor: Piotr Salachna

Received: 16 September 2021

Accepted: 6 October 2021

Published: 8 October 2021

Publisher's Note: MDPI stays neutral with regard to jurisdictional claims in published maps and institutional affiliations.

Copyright: (๑) 2021 by the authors Licensee MDPI, Basel, Switzerland. This article is an open access article distributed under the terms and conditions of the Creative Commons Attribution (CC BY) license (https:// creativecommons.org/licenses/by/ $4.0 /)$.

\begin{abstract}
Marigold is one of the commercially exploited flowering crops that belongs to the family Asteraceae. The production of economical yield and better quality of marigold flowers requires proper crop management techniques. Crop regulation is an important technique to make the marigold production profitable. This can be done by adopting application of plant growth regulators (PGRs). The present study was designed to investigate the effect of PGRs on flowering and antioxidant activity of two cultivars of African marigold (Tagetes erecta L.) viz. "Pusa Narangi Gainda" (hereinafter referred to as Narangi) and "Pusa Basanthi Gainda" (hereafter referred to as Basanthi). Plants were sprayed with abscisic acid (ABA), N-acetyl thiazolidine (NAD), gibberellic acid $\left(\mathrm{GA}_{3}\right)$, salicylic acid (SA), indole-3-butyric acid (IBA) and oxalic acid (OA) at the concentrations of 100, 150, 250, 300 and $800 \mathrm{mg} \cdot \mathrm{L}^{-1}$, each. Results revealed that the plants treated with $500-600 \mathrm{mg} \cdot \mathrm{L}^{-1}$ IBA exhibited maximum increase in floral diameter (34-51\%). The use of $500-550 \mathrm{mg} \cdot \mathrm{L}^{-1}$ IBA exhibited maximal enhancement in flower fresh weight (21-92\%). The exogenously applied OA significantly $(p \leq 0.05)$ improved flower dry weight, total phenolic contents, total flavonoid contents and reducing power ability of marigold plants. Overall, "Narangi" performed better than "Basanthi", in terms of flowering and antioxidant activity. Conclusively, the results suggest that foliar application of PGRs favors flowering and antioxidant activity of African marigold.
\end{abstract}

Keywords: plant growth regulators; salicylic acid; oxalic acid; DPPH; antioxidant activity; reducing power ability

\section{Introduction}

African marigold (Tagetes erecta L.) belongs to family Asteraceae and is one of the major and important commercial flower crops and widely grown for loose flower production [1] It is an ornamental plant species with known medicinal use due to the high content of carotenoids and phenolics in flower petals [2]. It is popular throughout the world because of its wide spectrum of attractive colours, shape and good keeping quality. Marigold has gained popularity on account of its easy cultivation, wide adaptability and production throughout the year [3]. Apart from beautification, its flower petals are also being used 
for xanthophyll production which is a major carotenoid fraction and accounts for $80-90 \%$ of lutein $[4,5]$. The flowers are also used for religious rituals and social functions because of their wide adoptability to varying soil and climatic conditions and long duration of flowering [6].

In many countries, research was conducted to improve flowering growth of ornamental plants by treating them with environment friendly substances, e.g., gibberellic acid, oxalic acid and salicylic acid, and success was achieved to a certain level [7]. Plant growth regulators (PGRs) play an important role in flower production, which in small amounts promotes or inhibits or quantitatively modifies growth and development. Gibberellic acid has proved to be very effective in manipulating growth and flowering in chrysanthemum (Chrysanthemum morifolium) [8] and petunia (Petunia hybrida) [9]. Gibberellic acid and NAA enhance the elongation and cell division by promoting the DNA synthesis in the cell. They reduced the juvenile phase due to increase in photosynthesis and respiration with enhanced $\mathrm{CO}_{2}$ fixation in the plant [10]. The flowering growth of marigold was reported as increased under the influence of abscisic acid [6]. Indole-3-butyric acid played a vital role in increasing floral diameter of rose species (Rosa spp.) by increasing cell division [11]. However, limited research was conducted in Pakistan using these PGRs to enhance growth and development of flowering plants [12].

Commercially, plant growth regulators are used for suppressing apical dominance retarding vegetative growth, lateral buds induction and the production of a large number of flowers in various crops resulting in a higher flower yield and easy cultivation [13-15]. There are many examples of utilization of plant growth hormones to regulate the flowering in aromatic plants [16]. This research is of great interest and importance for flower merchants, growers, and scientists in Pakistan. The traditionally used chemicals have negative impacts on the environment due to their nonbiodegradable characteristics [17]. Considering that there are not extensive studies about the effects of PGRs on flowering and antioxidant activity of African marigold, a pot experiment was designed to evaluate the floral growth and antioxidant response of two cultivars ("Pusa Narangi Gainda", (hereafter referred to as Narangi, and "Pusa Basanthi Gainda", hereafter referred to as Basanthi) of African marigold to exogenously applied different doses (100, 150, 250, 300 and $800 \mathrm{mg} \cdot \mathrm{L}^{-1}$ ) of PGRs, including abscisic acid (ABA), N-acetyl thiazolidine (NAD), gibberellic acid $\left(\mathrm{GA}_{3}\right)$, salicylic acid (SA), indole-3-butyric acid (IBA) and oxalic acid (OA).

\section{Materials and Methods}

\subsection{Plant Material and Experimental Site}

The experiment was conducted at the research farm of the Institute of Horticultural Sciences, University of Agriculture, Faisalabad, Pakistan $\left(31^{\circ} 26^{\prime} 03.3^{\prime \prime} \mathrm{N} 73^{\circ} 04^{\prime} 28.1^{\prime \prime} \mathrm{E}\right)$ from 16 July 2020 to 15 November 2020. One-month old seedlings of marigold cultivars "Pusa Narangi Gainda" and "Pusa Basanthi Gainda" were purchased from Qadir Bakhsh Nursery (Pvt. Ltd.), Faisalabad-38000, Pakistan, and transplanted to plastic pots $(30 \times 33 \mathrm{~cm})$, one seedling per pot. Before transplanting, the pots were filled with coconut coir, sand and well-pulverized soil collected from the field of the research farm with the ratio of 1:3:3, respectively. After filling growing media into pots, the moisture was applied up to field capacity. The pots media had $\mathrm{pH}, \mathrm{EC}$, available phosphorus and potassium of 6.3, $0.424 \mathrm{dS} \mathrm{m}{ }^{-1}, 14.92 \mathrm{mg} \cdot \mathrm{L}^{-1}$ and $347.57 \mathrm{mg} \cdot \mathrm{L}^{-1}$, respectively. After transplanting, pots were placed in a greenhouse. The greenhouse climate data during the complete execution of the experiment is given in Figure 1. 


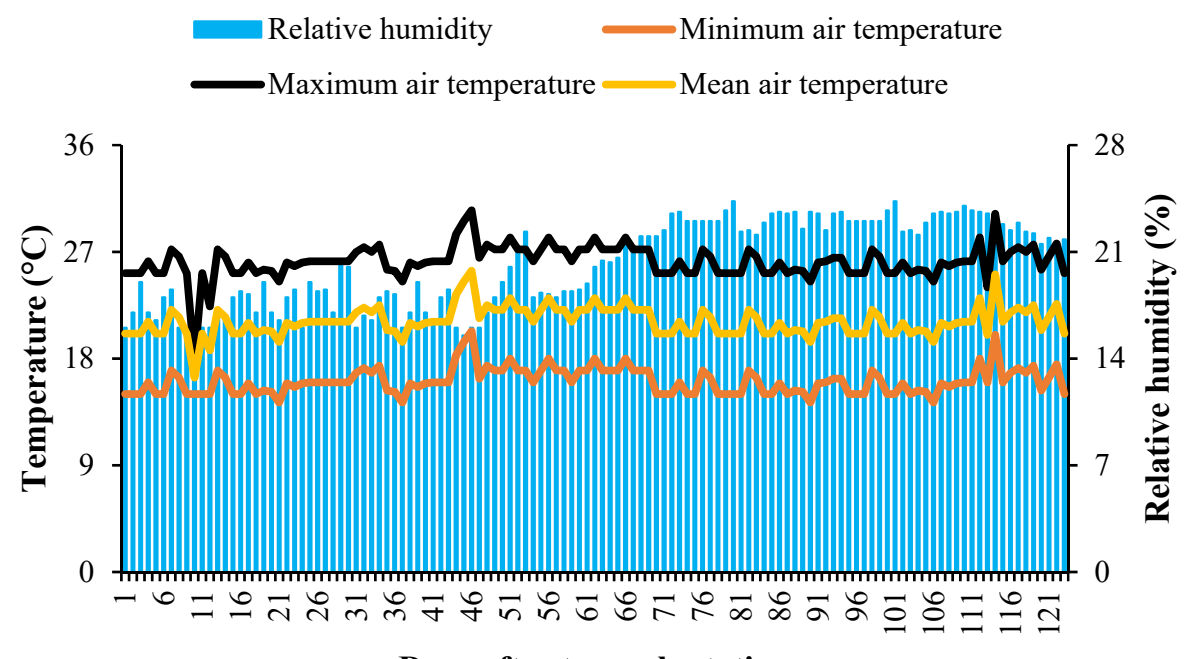

Days after transplantation

Figure 1. Microclimate conditions inside the greenhouse during the experiment (16 July to 15 November 2020) at research station of University of Agriculture, Faisalabad, Punjab, Pakistan.

\subsection{PGRs Treatments}

Marigold plants of both cultivars were sprayed with six different plant growth regulators (Merck KGaA, Darmstadt, Germany), namely abscisic acid (ABA), N-acetylthiazolidine (NAD), gibberellic acid $\left(\mathrm{GA}_{3}\right)$, salicylic acid (SA), indole-3-butyric acid (IBA) and oxalic acid (OA) at five different doses (i.e., 100, 150, 250, 300 and $800 \mathrm{mg} \cdot \mathrm{L}^{-1}$, each), twice a week from blooming, when each plant had $\geq 3$ flowers. Blooming initiated in both cultivars at same time ( $<2$ days difference). Each cultivar was sprayed with PGRs at the same time. The plants were sprayed one week after first bloom. Marigold plants were foliar sprayed with PGRs early in the morning using $1 \mathrm{~L}$ electronic sprayer (T Tovia, Ningbo, China) operated at a constant speed. Each treatment received $1 \mathrm{~L}$ of PGRs solution per spray. Control plants were treated with distilled water and maintained for comparison $\left(0 \mathrm{mg} \cdot \mathrm{L}^{-1}\right)$. Each treatment was replicated thrice, and each replication contained 10 pots, thus 10 plants.

\subsection{Flowering Attributes}

Flowering attributes, i.e., floral diameter, flower fresh weight and flower dry weight, were measured at full flower physiological maturity — determined by visual observation123 days after transplanting, after 4 weeks from the first spray, that is after 8 sprays. These parameters were calculated by randomly picking 10 physiologically mature flowers from 10 plants per replicate and per treatment. Floral diameter was measured with digital Vernier callipers (DR-MV0100NG, Ningbo Dongrun Imp. \& Exp. Co., Ltd., Ningbo, China), whereas flower weight was measured with digital weighing balance (MJ-W176P, Panasonic, Osaka, Japan). Fresh flowers were dried in hot air dehydrator (Ultimate 4000, Fowlers Vacola Australia Pty Ltd., Melbourne, Australia) at $65^{\circ} \mathrm{C}$ for $72 \mathrm{~h}$.

\subsection{Antioxidant Attributes}

\subsubsection{Sample Preparation}

The oven dried flowers were grinded and mixed in methanol to prepare sample solution $(1: 15 w / v)$. The mixture was stirred for $2 \mathrm{~h}$ and kept at room temperature for $24 \mathrm{~h}$. Then, it was filtered and kept in sealed bottles in the dark [18].

\subsubsection{Total Phenolic Contents}

The $1.0 \mathrm{~mL}$ of each sample solution and gallic acid standard solution $(20,40,60$, 80 and $\left.100 \mathrm{mg} \cdot \mathrm{L}^{-1}\right), 5 \mathrm{~mL}$ of Folin-Ciocalteu reagent and $4 \mathrm{~mL}$ sodium carbonate $(7 \%$ $w / v)$ were added in a flask and shaken to mix the components completely. After keeping 
all the samples in the dark for $30 \mathrm{~min}$, absorbance was measured at $765 \mathrm{~nm}$ using a spectrophotometer (T60 U Spectrophotometer, PG Instruments Ltd., Leicestershire, UK). Reagent solution was used as a blank. The amount of total phenolics was expressed as gallic acid equivalent in milligram per gram plant dry weight [19].

\subsubsection{Total Flavonoid Contents}

The $1.0 \mathrm{ml}$ of sample or catechin standard solution $\left(20,40,60,80\right.$ and $\left.100 \mathrm{mg} \cdot \mathrm{L}^{-1}\right)$ was mixed with $4.0 \mathrm{~mL}$ of water in $10 \mathrm{~mL}$ volumetric flask followed by addition of $0.3 \mathrm{~mL}$ of $5 \%$ $\mathrm{NaNO}_{2}$. After $5 \mathrm{~min}, 0.3 \mathrm{~mL}$ of $10 \% \mathrm{AlCl}_{3}$ was added and after waiting for one more min, $2 \mathrm{~mL}$ of $1 \mathrm{M} \mathrm{NaOH}$ were added, and total volume was made up to $10 \mathrm{~mL}$ using deionized distilled water (DDW). After mixing the solution properly, the absorbance reading was measured at $510 \mathrm{~nm}$ using reagent as blank. The amount of total flavonoids was expressed as catechin equivalent in milligram per gram plant dry weight [20].

\subsubsection{DPPH Free Radical Scavenging Activity}

The 1,1-diphenyl-2-picrylhydrazine (CAS No. 1707-75-1, $\geq 95 \%$ purity, Sigma-Aldrich, Milwaukee, WI, USA) scavenging activity was carried out by adding DPPH solution $(1.0 \mathrm{~mL}, 0.3 \mathrm{M})$ to $2.5 \mathrm{~mL}$ solution of plant extract or gallic acid standard. Then samples and standards were incubated at room temperature in the dark for $20 \mathrm{~min}$. Finally, absorbance was recorded at $518 \mathrm{~nm}$. The control solution was prepared by adding $1.0 \mathrm{~mL}$ of methanol to $2.5 \mathrm{~mL}$ of extract solution without DPPH, while the positive control was prepared by adding $1.0 \mathrm{~mL}$ of DPPH solutions to $2.5 \mathrm{~mL}$ of gallic acid. The DPPH scavenging activity was calculated using the following expression [21].

$$
\text { DPPH scavenging activity }(\%)=100-\left[\frac{\text { Absorbance of sample }}{\text { Absorbance of control }} \times 100\right]
$$

\subsubsection{Plant Reducing Power Ability}

The plant extract $(1.0 \mathrm{~mL})$ or gallic acid standard solution $\left(20,40,60,80\right.$ and $\left.100 \mathrm{mg} \cdot \mathrm{L}^{-1}\right)$ was mixed with $2.3 \mathrm{~mL}$ of $0.2 \mathrm{M}$ phosphate buffer ( $\mathrm{pH}$ 6.6) and $2.5 \mathrm{~mL}$ of $1 \%$ potassium ferricyanide $\left(\mathrm{K}_{3}\left[\mathrm{Fe}(\mathrm{CN})_{6}\right]\right)$. The mixture was incubated at $37^{\circ} \mathrm{C}$ for $20 \mathrm{~min}$. Then, $10 \%$ trichloroacetic acid $(2.5 \mathrm{~mL})$ was added to the mixture and centrifuged for $10 \mathrm{~min}$ at $1000 \mathrm{rpm}$, the supernatant $(2.5 \mathrm{~mL})$ was mixed with $2.5 \mathrm{~mL}$ of distilled water and $0.5 \mathrm{~mL}$ of $0.1 \% \mathrm{FeCl}_{3}$. After keeping the solution for $10 \mathrm{~min}$, the absorbance was measured at $700 \mathrm{~nm}[22]$.

\subsection{Experimental Design and Statistical Data Analysis}

The experiment was designed under bi-factorial completely randomized design (Cultivar $\times$ PGRs doses) with three replicates. Collected data were submitted to analysis of variance (ANOVA) and found that cultivars and PGR doses had significant $(p \leq 0.05)$ interaction, except in the case of flower diameter when treated with ABA and SA. Fisher's LSD (interaction) technique was used to compare treatment means $(p \leq 0.05)$ using the analytical software package "Statistix 8.1". Principle component analysis and correlation coefficient values were determined through Pearson $(n)$ technique using "XLSTAT ver. 2019".

\section{Results}

\subsection{Flowering Attributes}

Marigold plants of "Basanthi" exhibited more floral diameter as compared to "Narangi". In case of ABA application, marigold plants of "Basanthi" had a bigger floral diameter than "Narangi" ( $p \leq 0.05)$. The maximum floral diameter $(5.24 \mathrm{~cm})$ was observed in plants of "Basanthi" treated with $250 \mathrm{mg} \cdot \mathrm{L}^{-1} \mathrm{ABA}$ which was 1.34-fold greater than those of untreated plants (Figure 2A). Similarly, marigold plants of "basanthi" receiving foliar application of 100,300 and $800 \mathrm{mg} \cdot \mathrm{L}^{-1} \mathrm{NAD}$ exhibited a significant $(p \leq 0.05)$ increase in the floral diameter. However, for NAD application above than $250 \mathrm{mg} \cdot \mathrm{L}^{-1}$, a sharp 
decrease in the average was obtained for floral diameter, reaching $2.5 \mathrm{~cm}$ for the maximum dose applied (800 mg. $\mathrm{L}^{-1}$ ) (Figure 2B). Regardless of the concentration, plants of "Basanthi" showed enhanced floral diameter under the influence of $\mathrm{GA}_{3}$, while the plants of "Narangi" showed $28 \%$ increase in the floral diameter when treated with $800 \mathrm{mg} \cdot \mathrm{L}^{-1}$ $\mathrm{GA}_{3}$, as compared with control (Figure $2 \mathrm{C}$ ). Floral diameter of both cultivars under the influence of foliar application of SA was non-significantly improved (Figure 2D). Conversely, exogenously applied IBA significantly enhanced the floral diameter of "Basanthi". Maximum floral diameter $(6.25 \mathrm{~cm})$ was recorded in the plants of the same cultivar receiving foliar application of $150 \mathrm{mg} \cdot \mathrm{L}^{-1} \mathrm{IBA}$, followed by $800 \mathrm{mg} \cdot \mathrm{L}^{-1} \mathrm{IBA}$ which was 1.61 and 1.52-fold greater than those of untreated plants, respectively. The plants of "Narangi" showed non-significant but comparable results to control, except when treated with 300 and $800 \mathrm{mg} \cdot \mathrm{L}^{-1}$ IBA (Figure 2E). In the case of OA treatment, the plants treated with $300 \mathrm{mg} \cdot \mathrm{L}^{-1}$ OA showed maximum floral diameter $(5.59 \mathrm{~cm}$ "Narangi", $4.95 \mathrm{~cm}$ "Basanthi") in both cultivars as compared to control (Figure 2F).
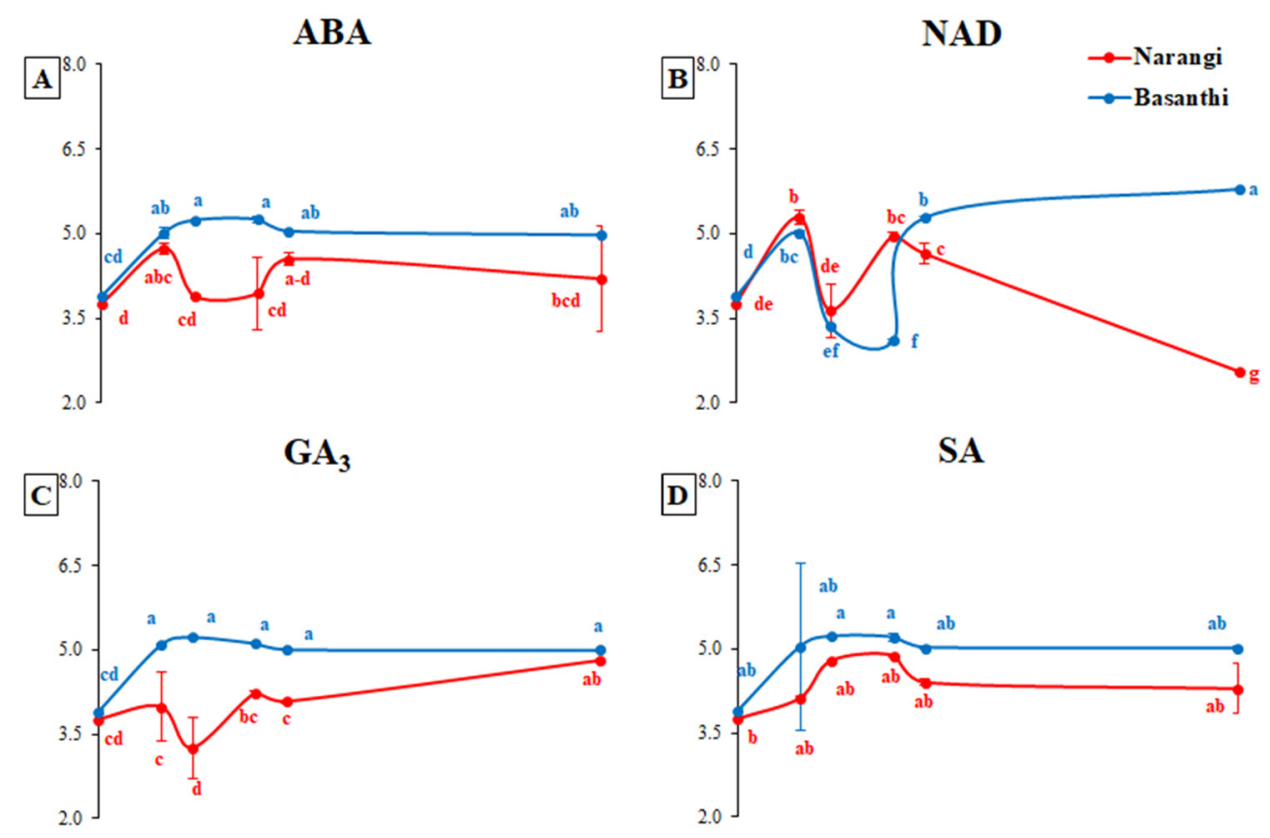

IBA
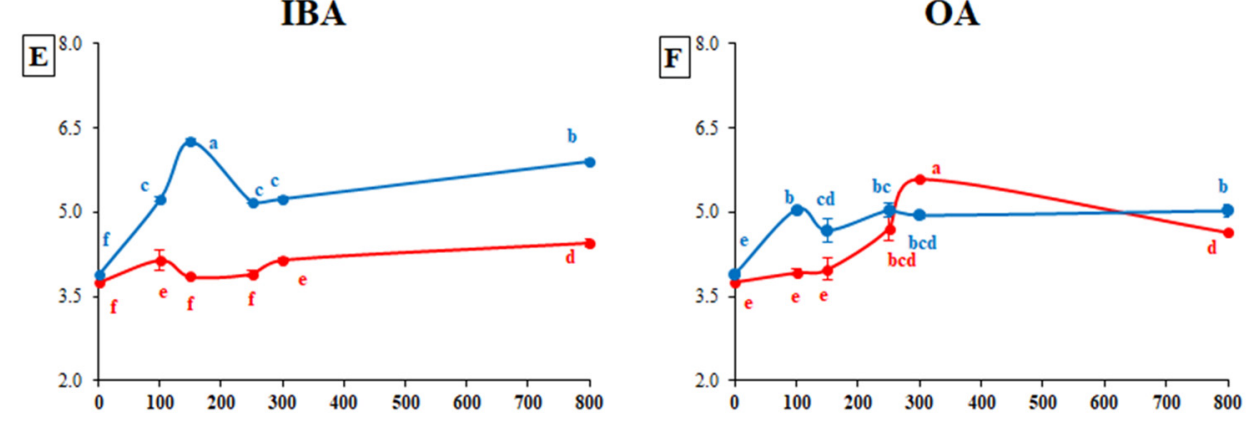

Figure 2. Floral diameter (cm) of two cultivars of marigold ("Pusa Narangi Gainda" and "Pusa Basanthi Gainda") as affected by different doses (mg. $\mathrm{L}^{-1}$ ) of ABA (A); NAD (B); GA 3 (C); SA (D); IBA (E) and OA (F). Same letters indicate non-significant difference among treatments under Fisher's least significant difference test $(p \leq 0.05)$. Vertical bars indicate average \pm standard error (three replications, under bi-factorial CRD).

In case of flower fresh weight, "Narangi" showed significant response to ABA application. Plants of "Narangi" treated with $300 \mathrm{mg} \cdot \mathrm{L}^{-1}$ ABA exhibited $62.53 \%$ increase in flower fresh weight as compared to control (Figure $3 \mathrm{~A}$ ). Under the influence of NAD, the plants of "Basanthi" receiving foliar application of 300 and $800 \mathrm{mg} \cdot \mathrm{L}^{-1} \mathrm{NAD}$ exhib- 
ited 85.74 and $43.88 \%$ increase in flower fresh weight, respectively. "Narangi" exhibited $93.55 \%$ increase in flower fresh weight when received $100-250 \mathrm{mg} \cdot \mathrm{L}^{-1} \mathrm{NAD}$ as compared to control (Figure 3B). In case of $\mathrm{GA}_{3}$ application, "Narangi" showed maximum flower fresh weight in plants treated with $800 \mathrm{mg} \cdot \mathrm{L}^{-1}(9.93 \mathrm{~g})$ which was $145.26 \%$ greater than untreated plants. Meanwhile, the flower fresh weight of "Basanthi" increased up to 15\% when treated with $\mathrm{GA}_{3}$ except when treated with $300 \mathrm{mg} \cdot \mathrm{L}^{-1} \mathrm{GA}_{3}$ (Figure 3C).
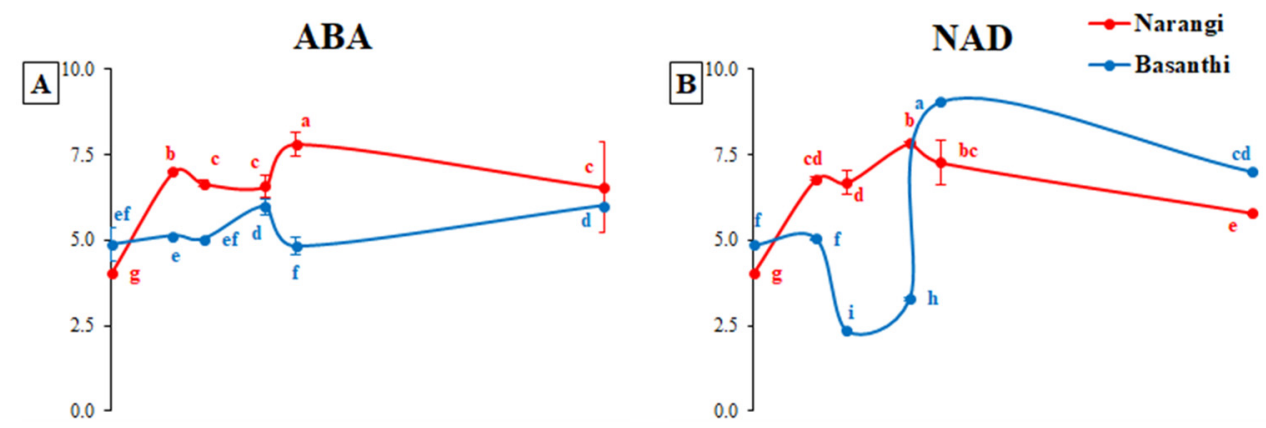

$\mathbf{G A}_{3}$
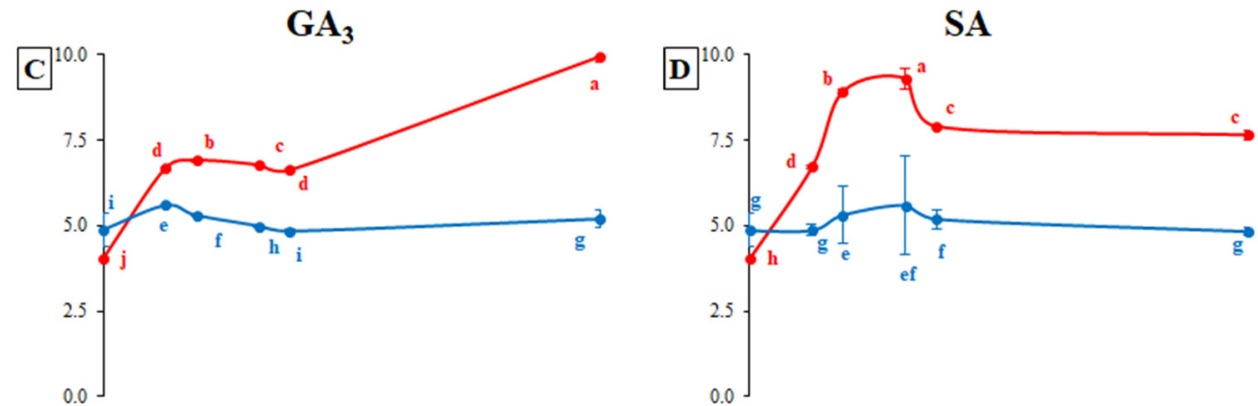

IBA
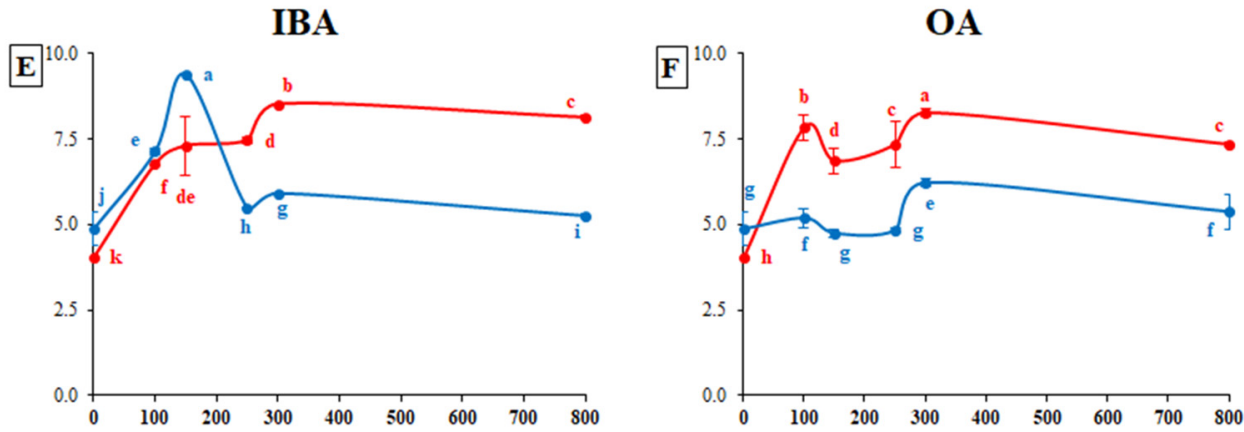

Figure 3. Flower fresh weight (g) of two cultivars of marigold ("Pusa Narangi Gainda" and "Pusa Basanthi Gainda") as affected by different doses (mg. $\mathrm{L}^{-1}$ ) of ABA (A); NAD (B); GA 3 (C); SA (D); IBA (E) and OA (F). Same letters indicate non-significant difference among treatments under Fisher's least significant difference test $(p \leq 0.05)$. Vertical bars indicate average \pm standard error (three replications, under bi-factorial CRD).

The foliar application of $250 \mathrm{mg} \cdot \mathrm{L}^{-1} \mathrm{SA}$ showed maximum flower fresh weight $(9.29 \mathrm{~g}$ "Narangi", 5.59 g "Basanthi") in both cultivars as compared to control (Figure 3D). Similarly, the plants of "Narangi" and "Basanthi" showed 110.23 and 92.80\% increase in flower fresh weight when treated with 300 and $150 \mathrm{mg} \cdot \mathrm{L}^{-1} \mathrm{IBA}$, respectively (Figure $3 \mathrm{E}$ ). The plants treated with foliar application of $300 \mathrm{mg} \cdot \mathrm{L}^{-1} \mathrm{OA}$ showed maximum flower fresh weight (8.25 g "Narangi", $6.24 \mathrm{~g}$ "Basanthi") followed by $100 \mathrm{mg} \cdot \mathrm{L}^{-1}$ (7.83 g "Narangi", $5.19 \mathrm{~g}$ "Basanthi") in both cultivars (Figure 3F).

"Basanthi" exhibited a $6.16 \%$ increase in flower dry weight when treated with $250 \mathrm{mg} \cdot \mathrm{L}^{-1}$ ABA, while "Narangi" showed a 1.45-fold better response under the influence of $800 \mathrm{mg} \cdot \mathrm{L}^{-1}$ ABA as compared to untreated plants (Figure 4A). The plants of "Basanthi" receiving foliar application of 100, 300 and $800 \mathrm{mg} \cdot \mathrm{L}^{-1}$ NAD exhibited 3.90, 9.43 and $7.62 \%$ increase in flower dry weight, while the plants treated with 150 and $250 \mathrm{mg} \cdot \mathrm{L}^{-1}$ NAD showed a 
1.47 and 0.845 decrease in flower dry weight as compared to control. Flower dry weight of "Narangi" increased up to 10\% with 100-300 mg. $\mathrm{L}^{-1}$ NAD as compared to control (Figure $4 \mathrm{~B}$ ). In case of $\mathrm{GA}_{3}$ application, "Narangi" and "Basanthi" showed maximum flower dry weight when treated with 800 and $100 \mathrm{mg} \cdot \mathrm{L}^{-1}$, which were 8.15 and $3.91 \%$ more than those of untreated plants (Figure 4C). The foliar application of 150 and $250 \mathrm{mg} \cdot \mathrm{L}^{-1} \mathrm{SA}$ showed 12.84 and $6.61 \%$ increment in flower dry weight of "Narangi" and "Basanthi", respectively (Figure 4D). Similarly, 800 and $300 \mathrm{mg} \cdot \mathrm{L}^{-1}$ IBA induced 6.09 and $6.47 \%$ increase in flower dry weight of the plants of "Narangi" and "Basanthi", respectively (Figure 4E). The plants treated with $300 \mathrm{mg} \cdot \mathrm{L}^{-1} \mathrm{OA}$ exhibited maximum flower dry weight $(1.41 \mathrm{~g}$ "Narangi", $0.84 \mathrm{~g}$ "Basanthi") (Figure 5F).

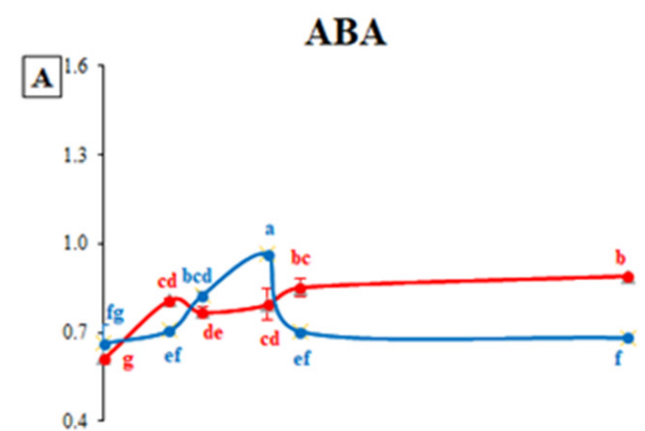

$\mathbf{G A}_{3}$

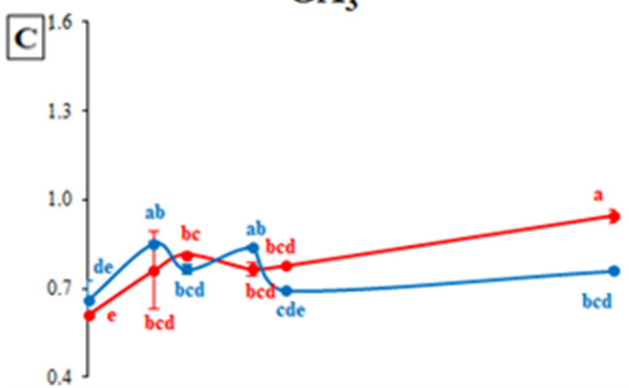

IBA

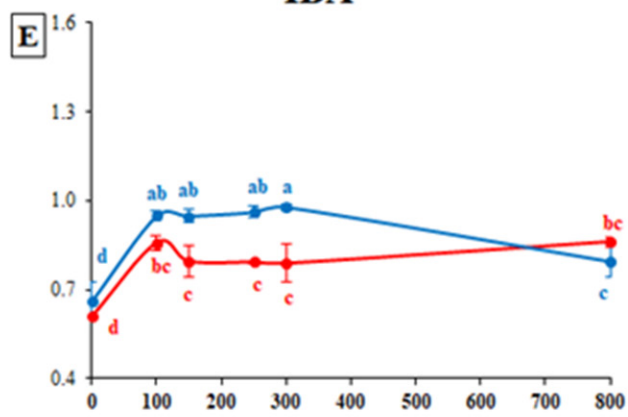

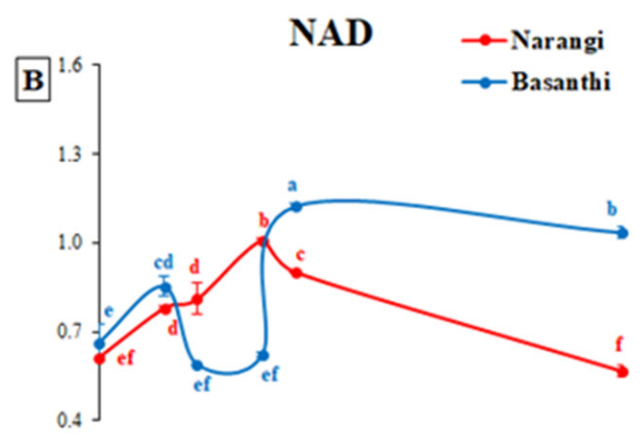

SA

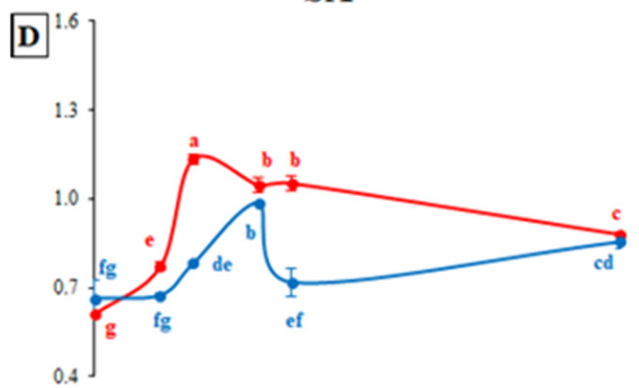

OA

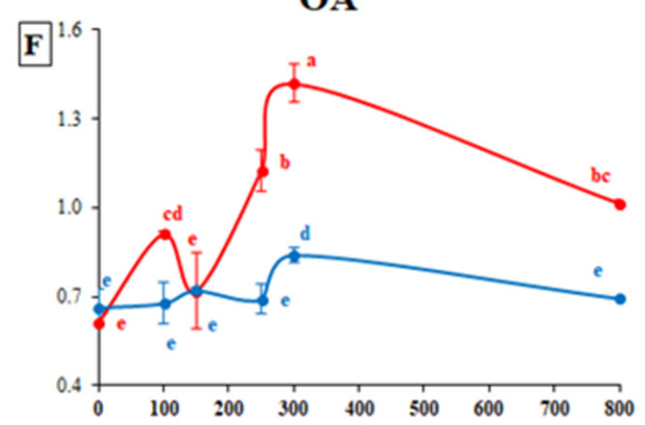

Figure 4. Flower dry weight (g) of two cultivars of marigold ("Pusa Narangi Gainda" and "Pusa Basanthi Gainda") as affected by different doses (mg. $\mathrm{L}^{-1}$ ) of ABA (A); NAD (B); GA 3 (C); SA (D); IBA (E) and OA (F). Same letters indicate non-significant difference among treatments under Fisher's least significant difference test $(p \leq 0.05)$. Vertical bars indicate average \pm standard error (three replications, under bi-factorial CRD). 

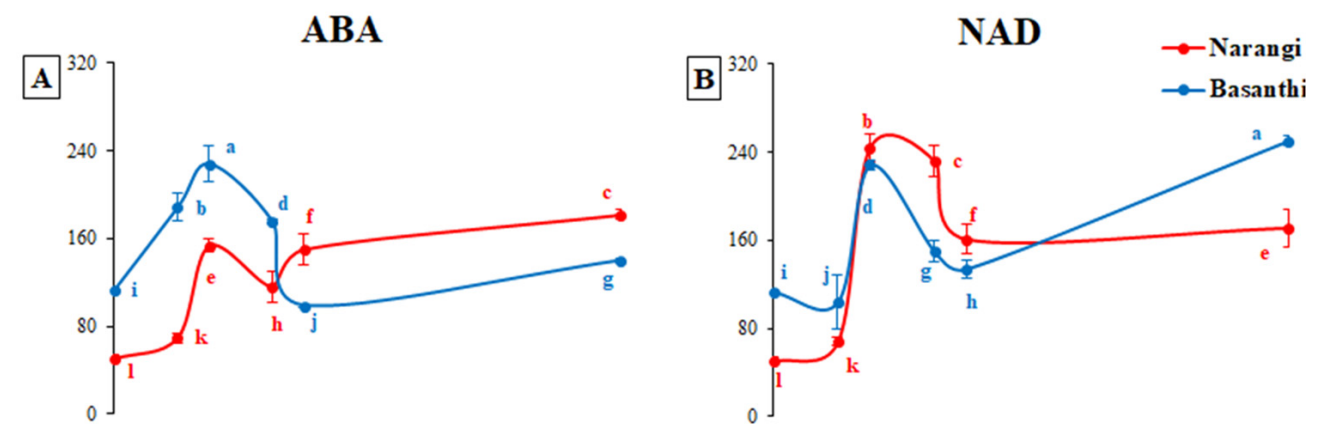

$\mathbf{G A}_{3}$

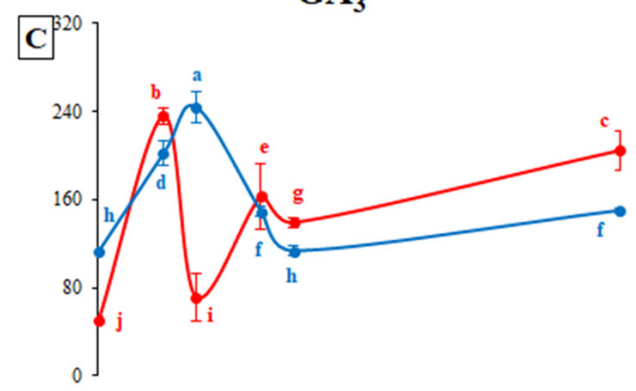

SA

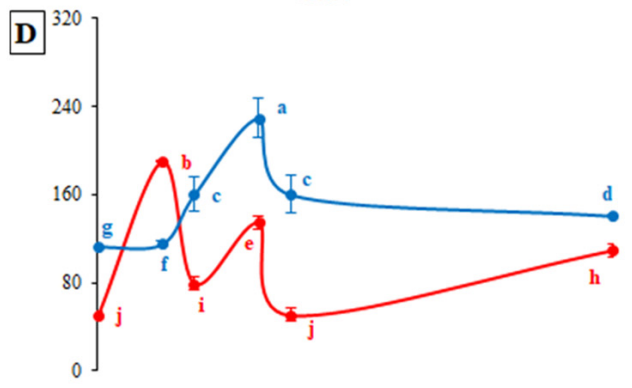

IBA
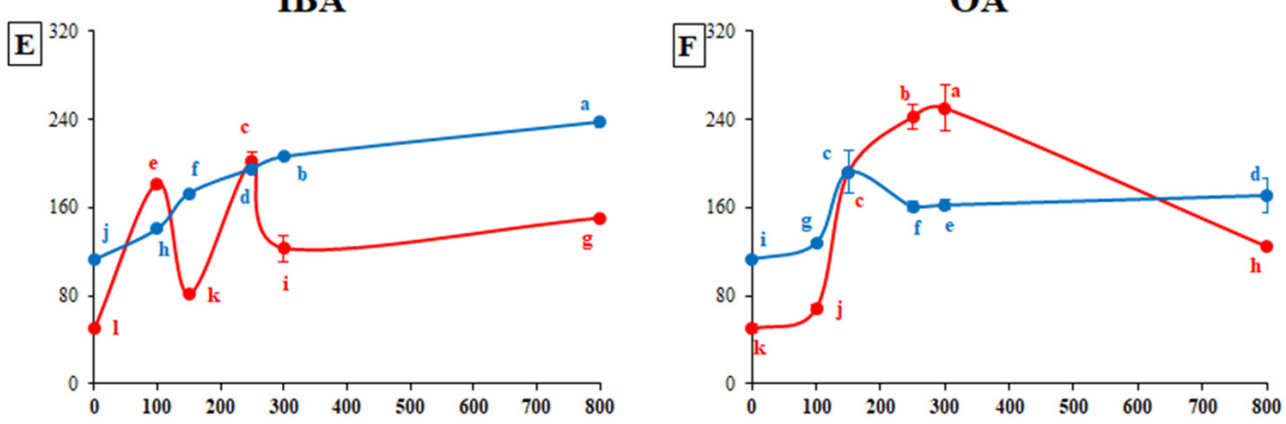

Figure 5. Total phenolic contents $\left(\mathrm{mg}^{-\mathrm{g}^{-1}}\right)$ of two cultivars of marigold ("Pusa Narangi Gainda" and "Pusa Basanthi Gainda") as affected by different doses $\left(\mathrm{mg} \cdot \mathrm{L}^{-1}\right)$ of ABA (A); NAD (B); GA 3 (C); SA (D); IBA (E) and OA (F). Same letters indicate non-significant difference among treatments under Fisher's least significant difference test $(p \leq 0.05)$. Vertical bars indicate average \pm standard error (three replications, under bi-factorial CRD).

\subsection{Antioxidant Attributes}

Marigold plants of "Basanthi" treated with $150 \mathrm{mg} \cdot \mathrm{L}^{-1}$ ABA showed enhanced phenolic contents by 2.02-fold comparing with untreated plants (Figure 5A). Similarly, plants receiving foliar application of $150-800 \mathrm{mg} \cdot \mathrm{L}^{-1} \mathrm{NAD}$ exhibited up to a $121.87 \%$ increase in total phenolics. Conversely, the plants treated with 100 NAD showed decreased phenolic contents by $8.11 \%$ as compared to control (Figure 5B). "Basanthi" and "Narangi" showed an 116.36 and $368.82 \%$ increase in total phenolics when treated with 150 and $100 \mathrm{mg} \cdot \mathrm{L}^{-1} \mathrm{GA}_{3}$, respectively (Figure 5C). Plants of "Basanthi" receiving a foliar application of $250 \mathrm{mg} \cdot \mathrm{L}^{-1}$ SA exhibited maximum phenolic contents $\left(229.63 \mathrm{mg} \cdot \mathrm{g}^{-1}\right.$ ) which were $103.53 \%$ more than those of untreated plants (Figure 5D). IBA enhanced the phenolics of both cultivars in a concentration dependent manner. Maximum phenolics $\left(237.47 \mathrm{mg} \cdot \mathrm{g}^{-1}\right)$ were recorded in the plants of "Basanthi" receiving foliar application of $800 \mathrm{mg} \cdot \mathrm{L}^{-1}$ IBA followed by the plants of same cultivar treated with $300 \mathrm{mg} \cdot \mathrm{L}^{-1}$ IBA (Figure 5E). "Basanthi" and "Narangi" showed 397.63 and $70.46 \%$ increase in phenolics when treated with 150 and $300 \mathrm{mg} \cdot \mathrm{L}^{-1}$ SA, respectively (Figure 5F).

The flavonoid contents of "Narangi" were recorded $69.56 \%$ more as compared to control when treated with $250 \mathrm{mg} \cdot \mathrm{L}^{-1} \mathrm{ABA}$ (Figure $6 \mathrm{~A}$ ). The plants of both cultivars 
receiving foliar application of 100, 150, $800 \mathrm{mg} \cdot \mathrm{L}^{-1} \mathrm{NAD}$ exhibited a significant increase in total flavonoids, while the plants of "Narangi" treated with 250 and 300 NAD showed decreased flavonoid contents as compared to the control (Figure 6B). The plants of "Basanthi" and "Narangi" treated with 300 and $100 \mathrm{mg} \cdot \mathrm{L}^{-1} \mathrm{GA}_{3}$ showed a 2.85 - and 2.04-fold increase in flavonoid contents as compared to untreated plants (Figure 6C). In case of SA application, total flavonoids of "Basanthi" significantly increased with the application of 250 and $300 \mathrm{mg} \cdot \mathrm{L}^{-1} \mathrm{SA}$, while "Narangi" exhibited enhanced flavonoids as the result of 100 and $800 \mathrm{mg} \cdot \mathrm{L}^{-1} \mathrm{SA}$ (Figure 6D). IBA at 250 and $800 \mathrm{mg} \cdot \mathrm{L}^{-1}$ enhanced the flavonoid contents of both cultivars by 1.89 and 2.88-fold, respectively. Maximum flavonoids $\left(98.34 \mathrm{mg} \cdot \mathrm{g}^{-1}\right)$ were recorded in the plants of "Basanthi" receiving foliar application of $800 \mathrm{mg} \cdot \mathrm{L}^{-1}$ IBA (Figure $6 \mathrm{E}$ ). The plants of "Basanthi" treated with $250 \mathrm{mg} \cdot \mathrm{L}^{-1}$ $\mathrm{OA}$ and "Narangi" treated with $150 \mathrm{mg} \cdot \mathrm{L}^{-1} \mathrm{OA}$ showed maximum level of flavonoid contents (75.32 and $100.51 \mathrm{mg} \cdot \mathrm{g}^{-1}$, respectively) (Figure $6 \mathrm{~F}$ ).
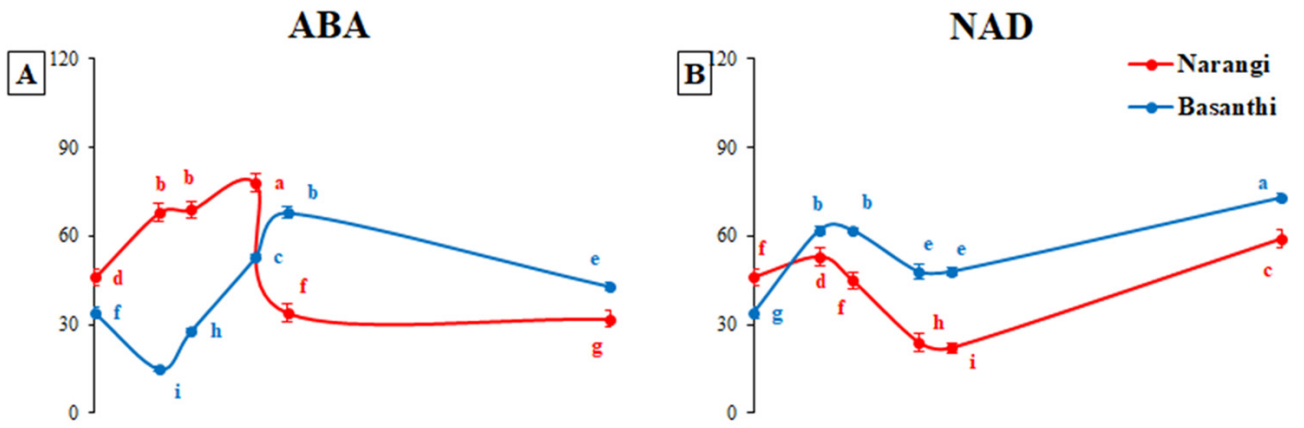

$\mathbf{G A}_{3}$
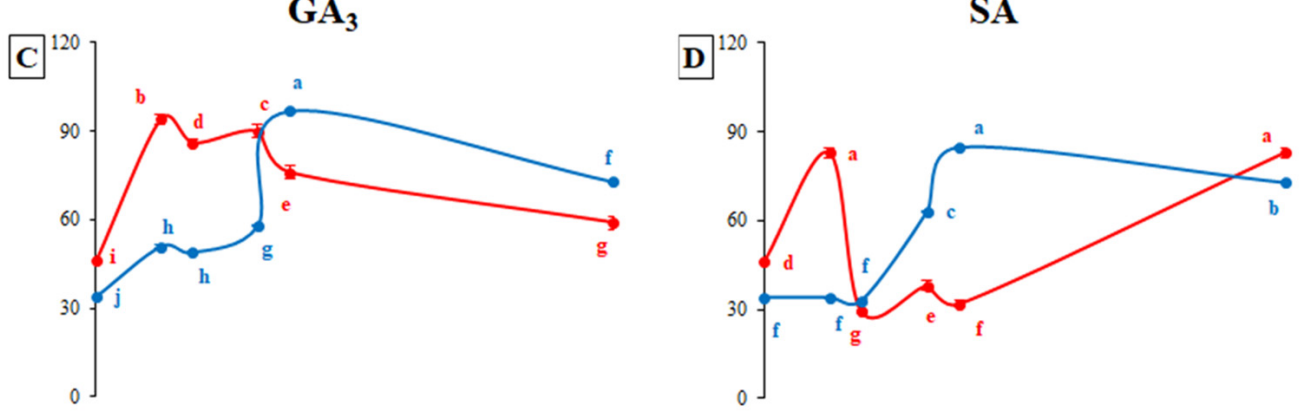

IBA
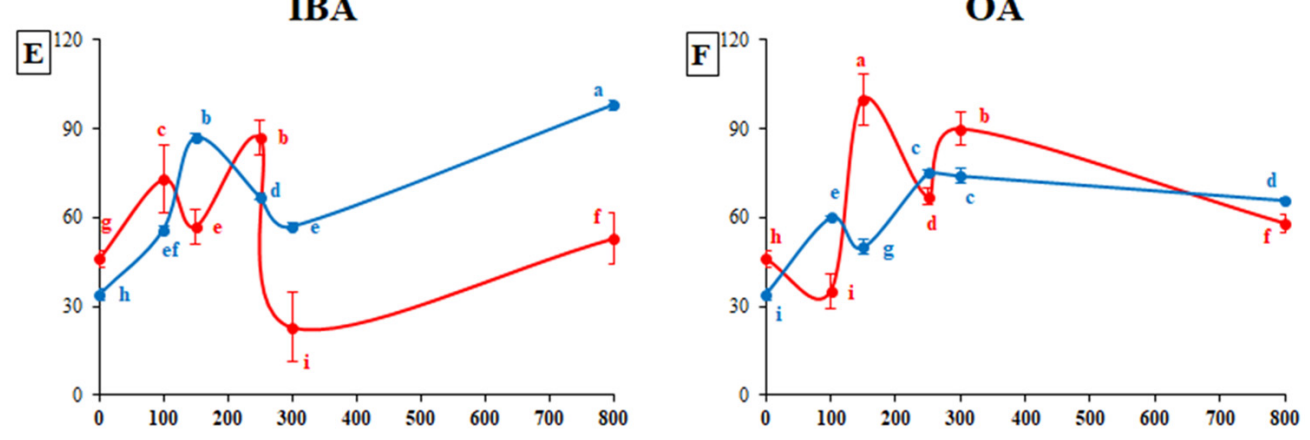

Figure 6. Total flavonoid contents $\left(\mathrm{mg}^{-\mathrm{g}^{-1}}\right.$ ) of two cultivars of marigold ("Pusa Narangi Gainda" and "Pusa Basanthi Gainda") as affected by different doses $\left(\mathrm{mg} \cdot \mathrm{L}^{-1}\right)$ of ABA (A); NAD (B); GA $3(\mathbf{C})$; SA (D); IBA (E) and OA (F). Same letters indicate non-significant difference among treatments under Fisher's least significant difference test $(p \leq 0.05)$. Vertical bars indicate average \pm standard error (three replications, under bi-factorial CRD).

The maximum floral DPPH free radical scavenging activity $(29.32 \%)$ was observed in plants of "Basanthi" treated with $800 \mathrm{mg} \cdot \mathrm{L}^{-1} \mathrm{ABA}$ which was $24.65 \%$ more than those of untreated plants (Figure 7A). The plants of "Narangi" treated with 100, 150 and 800 NAD, 
and "Basanthi" treated with 100 and 250-800 showed increase in DPPH activity up to 55 and $88 \%$, respectively, as compared to control (Figure 7B). In case of $\mathrm{GA}_{3}$, plants of "Narangi" showed reduction in DPPH activity, while the plants of "Basanthi" showed increased DPPH activity in a dose dependent manner (Figure 7C). The graph of SA (Figure 7D) showed opposite trend among both cultivars. The plants of "Basanthi" receiving foliar application of $800 \mathrm{mg} \cdot \mathrm{L}^{-1}$ IBA exhibited maximum DPPH scavenging activity (35.73\%) followed by the plants of "Narangi" receiving $150 \mathrm{mg} \cdot \mathrm{L}^{-1} \mathrm{IBA}(30.77 \%)$, which were 169.25 and $28.20 \%$ more than those of untreated plants of respective cultivars (Figure $7 \mathrm{E}$ ). The exogenously applied OA also enhanced the DPPH of both cultivars except when applied at the concentration of 800 and $150 \mathrm{mg} \cdot \mathrm{L}^{-1}$ in "Basanthi" and "Narangi", respectively (Figure 7F).

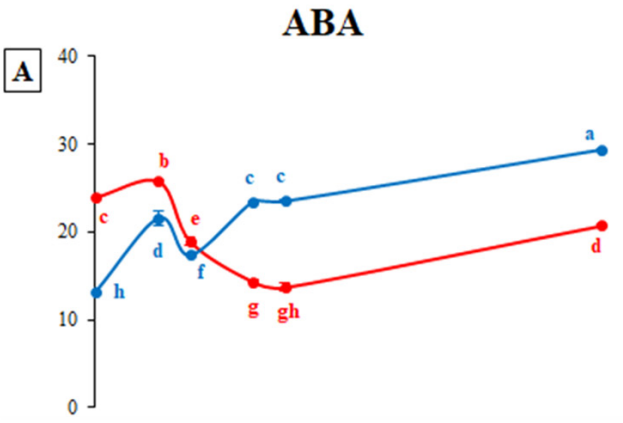

$\mathbf{G A}_{3}$

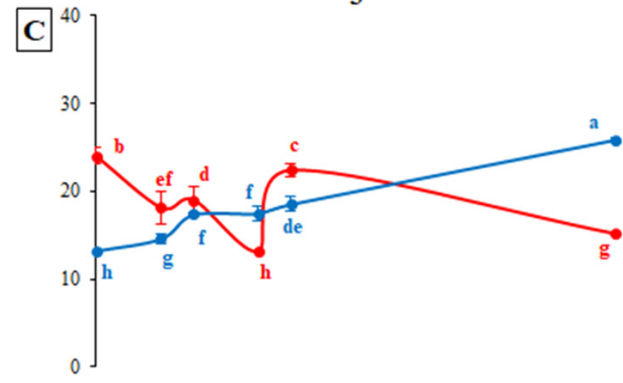

IBA

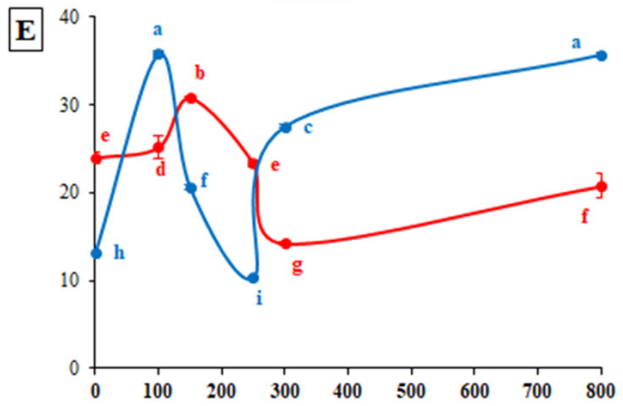

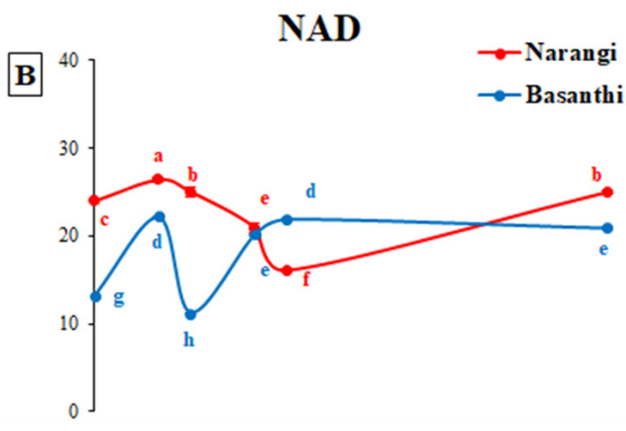

SA

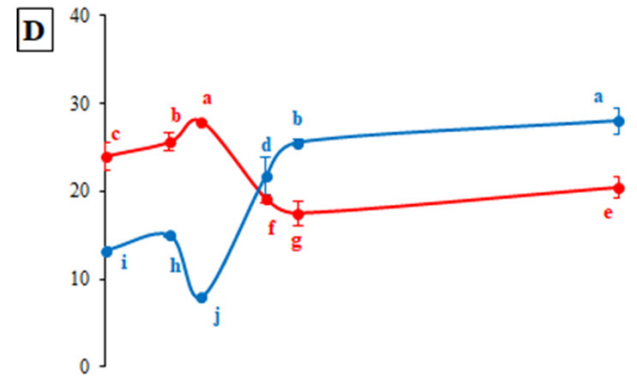

OA

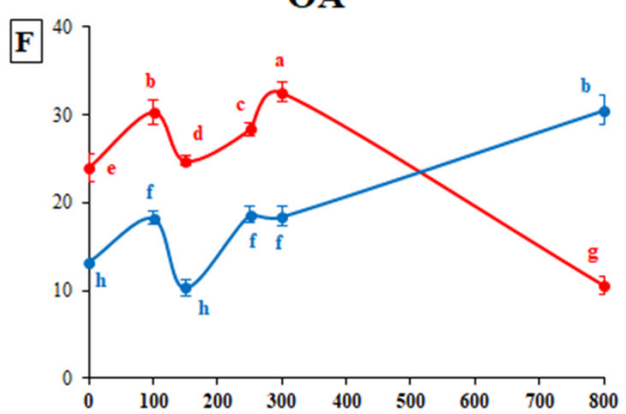

Figure 7. The DPPH free radical scavenging activity (\%) of two cultivars of marigold ("Pusa Narangi Gainda" and "Pusa Basanthi Gainda") as affected by different doses of (mg. $\left.\mathrm{L}^{-1}\right)$ ABA (A); NAD (B); GA 3 (C); SA (D); IBA (E) and OA (F). Same letters indicate non-significant difference among treatments under Fisher's least significant difference test $(p \leq 0.05)$. Vertical bars indicate average \pm standard error (three replications, under bi-factorial CRD).

ABA enhanced the reducing power ability (RPA) of the plants of "Basanthi" by 1.67-fold when treated with $100 \mathrm{mg} \cdot \mathrm{L}^{-1}$ (Figure 8A). Similarly, plants receiving foliar application of NAD exhibited 1.6-times more RPA as compared to control (Figure 8B). In the case of $\mathrm{GA}_{3}$ treatment, plants of "Basanthi" treated with $300 \mathrm{mg} \cdot \mathrm{L}^{-1}$ and plants "Narangi" treated with $100 \mathrm{mg} \cdot \mathrm{L}^{-1}$ showed maximum RPA (84.72 and $84.45 \mathrm{mg} \cdot \mathrm{g}^{-1}$, respectively), which were 59.03 and $44.48 \%$ more than those of untreated plants (Figure 8C). The RPA of 
both cultivars under the influence of foliar application of SA was significantly improved. Plants of "Basanthi" receiving foliar application of $250 \mathrm{mg} \cdot \mathrm{L}^{-1} \mathrm{SA}$ exhibited a $59.21 \%$ increase in RPA as compared to the control, which was maximum among all other dose of SA (Figure 8D). The exogenously applied IBA enhanced the RPA of both cultivars except when treated at the concentration of $800 \mathrm{mg} \cdot \mathrm{L}^{-1}$. Maximum RPA $\left(84.09 \mathrm{mg} \cdot \mathrm{g}^{-1}\right.$ "Narangi", $78.83 \mathrm{mg} \cdot \mathrm{g}^{-1}$ "Basanthi") was recorded in the plants receiving a foliar application of $150 \mathrm{mg} \cdot \mathrm{L}^{-1}$ IBA (Figure 8E). In the case of OA treatment, "Basanthi" and "Narangi" were treated with 300 and $150 \mathrm{mg} \cdot \mathrm{L}^{-1}$, respectively, showed maximum RPA (77.23 and $80.36 \mathrm{mg} \cdot \mathrm{g}^{-1}$, respectively) (Figure $8 \mathrm{~F}$ ).

ABA

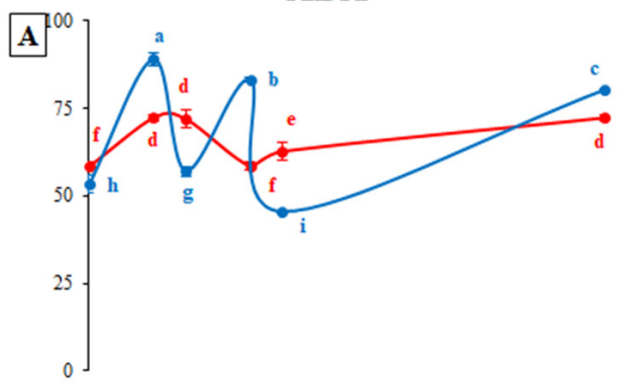

$\mathbf{G A}_{3}$

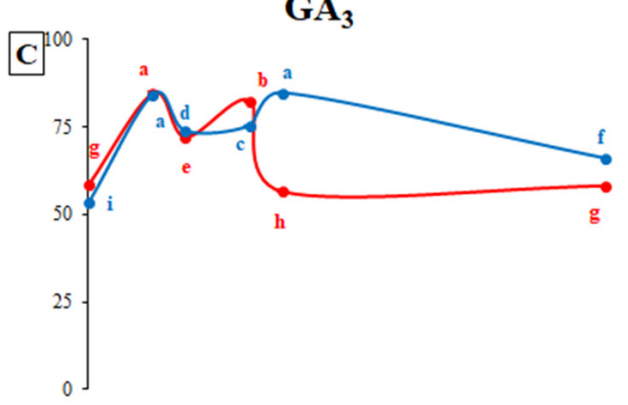

IBA

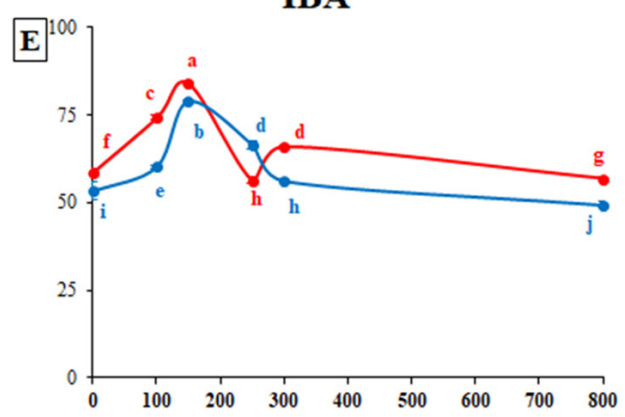

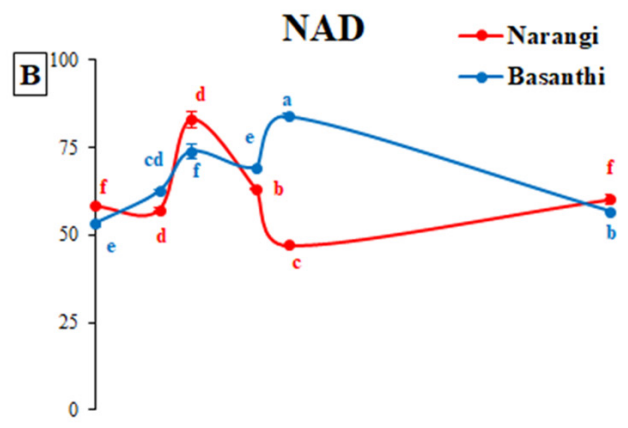

SA

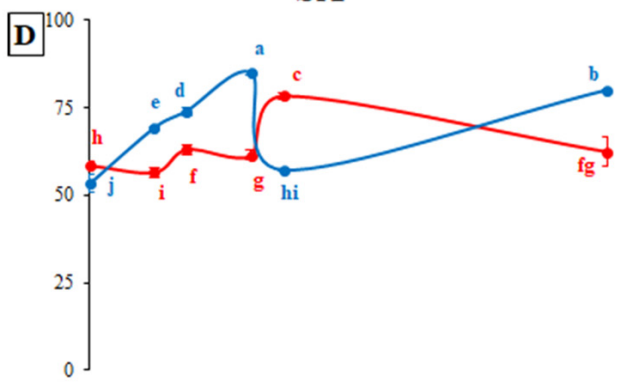

OA

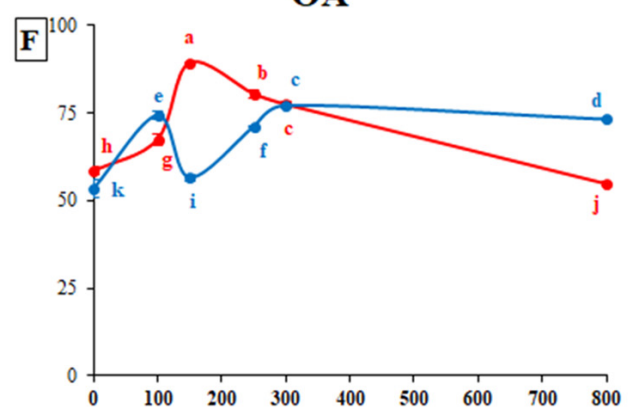

Figure 8. The reducing power ability $\left(\mathrm{mg}^{-\mathrm{g}^{-1}}\right)$ of two cultivars of marigold ("Pusa Narangi Gainda" and "Pusa Basanthi Gainda") as affected by different doses of $\left(\mathrm{mg} \cdot \mathrm{L}^{-1}\right)$ ABA (A); NAD (B); GA 3 (C); SA (D); IBA (E) and OA (F). Same letters indicate non-significant difference among treatments under Fisher's least significant difference test $(p \leq 0.05)$. Vertical bars indicate average \pm standard error (three replications, under bi-factorial CRD).

\subsection{Principle Component Analysis}

The efficacy of PGRs to modulate plant physiology depends on its concentration, application method and plant genetics [15]. Results from this study also showed that the response of marigold flower growth and antioxidant capacity to PGRs application changed with a change in the concentration and type of hormone. So, principal component analysis was conducted to delineate the concentration and PGR-dependent effects (Figure 9). Based on the highest squared cosine value corresponding to factors F1, F2 or F3, flower growth and quality attributes were clustered around PGR treatments. Factor F1, covering 
$20.23 \%$ variability in data (eigenvalue 2.833), showed clustering of flower diameter, flower fresh weight, flower dry weight and DPPH activity of "Basanthi" with 150-300 mg. $\mathrm{L}^{-1}$ $\mathrm{NAD}, 100 \mathrm{mg} \cdot \mathrm{L}^{-1} \mathrm{SA}, 150 \mathrm{mg} \cdot \mathrm{L}^{-1} \mathrm{IBA}, 300 \mathrm{mg} \cdot \mathrm{L}^{-1} \mathrm{IBA}$ and $150 \mathrm{mg} \cdot \mathrm{L}^{-1} \mathrm{OA}$ suggesting a positive influence of these treatments on these parameters. The second factor, covering $18.81 \%$ variability in data (eigen value 2.634 ), showed clustering of flower diameter, flower fresh weight and flower dry weight of "Narangi" with $150 \mathrm{mg} \cdot \mathrm{L}^{-1} \mathrm{ABA}, 800 \mathrm{mg} \cdot \mathrm{L}^{-1}$ $\mathrm{NAD}, 150 \mathrm{mg} \cdot \mathrm{L}^{-1} \mathrm{GA}_{3}, 800 \mathrm{mg} \cdot \mathrm{L}^{-1} \mathrm{GA}_{3}$ and $800 \mathrm{mg} \cdot \mathrm{L}^{-1} \mathrm{OA}$. However, the distribution of clusters in two distinct groups on opposite sides of $\mathrm{F} 1$ axis indicated that application of the aforementioned PGRs had strong negative correlations with flower diameter, flower fresh weight and flower dry weight of "Narangi". The third factor of principal component analysis, covering $13.41 \%$ variability in data (eigenvalue 1.877; not shown), showed clustering of total phenolics and reducing power ability of "Narangi" with foliar application of $300 \mathrm{mg} \cdot \mathrm{L}^{-1} \mathrm{ABA}, 100 \mathrm{mg} \cdot \mathrm{L}^{-1} \mathrm{NAD}, 100 \mathrm{mg} \cdot \mathrm{L}^{-1} \mathrm{GA}_{3}$ and $250-300 \mathrm{mg} \cdot \mathrm{L}^{-1} \mathrm{OA}$. Thus, principal component analysis helped to delineate individual roles of PGRs with respect to their concentrations in regulating various aspects of flower growth and antioxidant attributes of African marigold.

\section{Biplot (axes F1 and F2)}

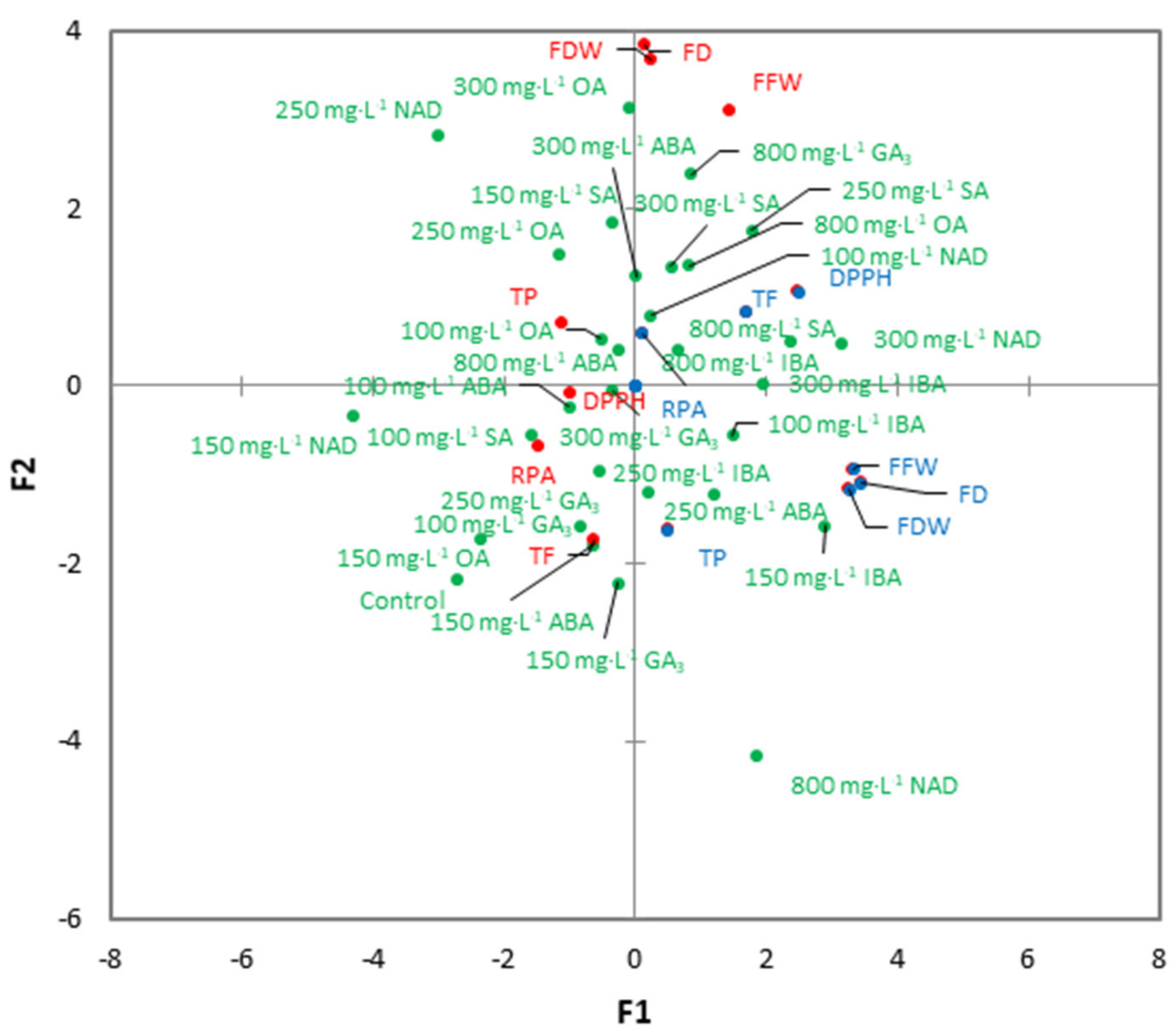

Figure 9. Principal component analysis among PGRs treatments and various flower growth and antioxidant attributes of two cultivars of marigold ("Pusa Narangi Gainda" and "Pusa Basanthi Gainda"). The treatments are shown in green colour, while variables of "Narangi" and "Basanthi" are indicated by red and blue coloured labels, respectively. Abbreviations: FD-flower diameter; FFW—flower fresh weight; FDW-flower dry weight; TP—-total phenolics; TF-total flavonoids; $\mathrm{DPPH}-\mathrm{DPPH}$ free radical scavenging activity; RPA—reducing power ability. 


\section{Discussion}

\subsection{Flowering Attributes}

Plant growth regulators play an important role in flower production, which in small amounts promotes or inhibits or quantitatively modifies growth and development [23]. In the current study, the impact of different PGRs on floral size, weight, and some antioxidant attributes of two cultivars of African marigold, i.e., "Basanthi" and "Narangi" was evaluated. In terms of floral diameter, both cultivars differentially responded to different PGRs. "Basanthi" exhibited a $60 \%$ increase in floral diameter under the influence of $150 \mathrm{mg} \cdot \mathrm{L}^{-1} \mathrm{IBA}$, while "Narangi" showed its maximum response ( $48 \%$ enhancement) under $300 \mathrm{mg} \cdot \mathrm{L}^{-1} \mathrm{OA}$. ABA, NAD, GA 3 , and SA also increased the floral diameter of marigold up to 35, 48, 34 and 34\%, respectively (Figure 2). Riaz et al. [6], Mitchell and Stewart [24], and Dhuma et al. [25] reported similar results in marigold and tuberose under the influence of $\mathrm{ABA}$ and $\mathrm{NAD}$. The $\mathrm{GA}_{3}$-induced increment in floral diameter might be due to more synthate translocation to only a fewer sink. A similar effect of $\mathrm{GA}_{3}$ was reported earlier in marigold and chrysanthemum [26-30]. The increase in floral diameter under the influence of SA was stated as the result of increased $\mathrm{CO}_{2}$ assimilation, photosynthetic rate and mineral uptake as supported by previous studies [31]. Some researchers reported similar findings in calendula and marigold [32,33]. IBA plays a vital role in increasing cell division [11], and hence found a promising way to improve floral diameter of marigold. Our results about the influence of IBA and OA on floral diameter of marigold are supported by previous findings in marigold, red firespike (Odontonema strictum), and henna (Lawsonia Inermis) [34-37].

It was reported earlier that $\mathrm{ABA}$ is consistently effective at reducing water loss and increasing flower fresh weight of bedding plants [38]. NAD represents one of the cornerstones of cellular oxidation and is essential for plant growth and development [39]. In our findings, "Narangi" exhibited $145 \%$ more fresh weight while receiving $800 \mathrm{mg} \cdot \mathrm{L}^{-1} \mathrm{GA}_{3}$, as compared to untreated plants, $57 \%$ more than the maximum observed in the plants of "Basanthi". The plants of both cultivars treated with PGRs exhibited more flower fresh weight as compared to untreated plants (Figure 3). The increase in fresh weight of marigold flowers with $\mathrm{GA}_{3}$ might be due to the production of bigger sized flowers. This might be attributed to rapid synthesis in the cell, increase in cell size, cell elongation and rapid translocation of assimilates to sink under the influence of phytohormones [40]. SA is an emerging plant growth regulator that acts as signaling molecule in plants under biotic and abiotic stresses in marigold. SA also exerts a stimulatory effect on different physiological processes of plant growth [41]. In case of IBA treatment, the plants of both cultivars treated with $150 \mathrm{mg} \cdot \mathrm{L}^{-1}$ IBA exhibited maximum flowers fresh weight. The reason behind the increase in flowers' fresh weight might be the enhancement of photosynthesis and maximum accumulation of photosynthates due to IBA application [42]. Similar results were also reported in marigold [35,43,44].

In terms of flower dry weight, "Narangi" responded better to PGRs as compared to "Basanthi". The maximum flower dry weight under the influence of PGRs was observed in the plants of "Narangi" when treated with $300 \mathrm{mg} \cdot \mathrm{L}^{-1} \mathrm{OA}$. The plants of "Basanthi" receiving similar dose of NAD exhibited $69 \%$ more flower dry weight as compared to those of untreated plants. Other applied PGRs i.e., $\mathrm{ABA}, \mathrm{GA}_{3}, \mathrm{SA}$ and IBA induced a significant increase in flower dry weight of marigold up to $45,53,84$ and $47 \%$, respectively (Figure 4). The results about $\mathrm{ABA}$ and $\mathrm{GA}_{3}$-induced floral dry weight are supported by previous findings, stating the role of PGRs in reducing water loss in the plants [28,45-49]. The results about IBA-induced flower dry weight was supported by Pacheco et al. [50] and Choudhary et al. [51] in marigold, and Pal [52] in calendula. Moreover, it was also reported that dry weight is well known to exhibit a high positive correlation with fresh weight of marigold flowers [53,54]. 


\subsection{Antioxidant Attributes}

Phenolic compounds are the secondary metabolites acting as antioxidants due to their hydroxyl group [55]. PGRs play an important role in improving antioxidant capacity of the plants. ABA was reported as having a key role in the enhancement of antioxidant capacity, anthocyanins and phenolic content of bedding plants (i.e., Impatiens walleriana, Pelargonium hortorum, Petunia hybrida, Tagetes patula, Salvia splendens, and Viola wittrockiana) [38]. In the current study, the total phenolics (floral extract) of both cultivars of Tagetes erecta were significantly influenced by different PGRs. Moreover, "Narangi" responded better to PGRs as compared to "Basanthi". The maximum phenolics were observed in the plants of "Narangi" and "Basanthi" under the influence of $300 \mathrm{mg} \cdot \mathrm{L}^{-1} \mathrm{OA}$ and $800 \mathrm{mg} \cdot \mathrm{L}^{-1} \mathrm{NAD}$ (Figure 5).

The effect of different PGRs on total flavonoid contents of floral extract of Tagetes erecta was found significant. $\mathrm{ABA}, \mathrm{NAD}, \mathrm{GA}_{3}, \mathrm{SA}, \mathrm{IBA}$ and $\mathrm{OA}$ increased floral flavonoids of marigold up to $70,114,185,114,188$ and $120 \%$, respectively. Marigold plants treated with maximum dose $\left(800 \mathrm{mg} \cdot \mathrm{L}^{-1}\right)$ of PGRs found having maximum flavonoids among other PGR doses (Figure 6). The increase in flavonoid contents was earlier reported in Taraxacum officinale [56] and Zinnia elegans [57] under the influence of $\mathrm{GA}_{3}$ and SA application, respectively. IBA stimulated the production of total flavonoids in Thymus vulgaris and Origanum vulgare, but decreased it in Ocimum basilicum [58,59]. Likewise, OA-induced flavonoid contents were reported in Bellis perennis [60].

The DPPH free radical scavenging activity is considered as an acceptable mechanism to evaluate the antioxidant activity of plants [61]. The plants of "Basanthi" showed a variation of DPPH activity from the lowest value (7\%) to the highest value (35.8\%). The plants treated with 100 and $800 \mathrm{mg} \cdot \mathrm{L}^{-1}$ IBA showed the highest value of free radical scavenging activity. Similarly, the plants of "Narangi" also showed varied DPPH activity from the lowest value (10\%) to the highest value (35.8\%). The plants of "Narangi" treated with $300 \mathrm{mg} \cdot \mathrm{L}^{-1} \mathrm{OA}$ exhibited maximum DPPH activity (Figure 7). Previously, it was reported that methanolic extract of Tagetes erecta exhibited 15.63 to $95.34 \%$ DPPH scavenging activity [62]. The antioxidant activity of plant extracts was found strongly associated with the reducing power of bioactive compounds [63]. Thus, the reducing power ability of marigold plants were determined. Our results suggest that the exogenously supplied PGRs significantly improved the reducing power ability of both cultivars (Figure 8). Similar findings in marigold were reported by some researchers [62,64].

\section{Conclusions}

PGRs play an important role in flower production, which in small amount promotes or inhibits or quantitatively modifies growth and development. In the present study, foliar application with different concentrations $\left(0,100,150,250,300\right.$ and $\left.800 \mathrm{mg} \cdot \mathrm{L}^{-1}\right)$ of $\mathrm{ABA}$, $\mathrm{NAD}, \mathrm{GA}_{3}, \mathrm{SA}$, IBA and OA proved to be successful for enhancing flowering and antioxidant activity of two cultivars of African marigold. This was evidenced by the improved diameter, fresh weight, dry weight, phenolics, flavonoids, DPPH free radical scavenging activity and reducing power ability of flowers, in which the doses were increased to a certain extent, after then a detrimental effect, although not lethal, was registered. Since foliar applications of PGRs differentially regulate distinct aspects of flowers growth, specific concentrations of PGRs may help to achieve some specific quality objectives of the flowers, commercially valuable. Among the foliar applied PGRs, $150 \mathrm{mg} \cdot \mathrm{L}^{-1} \mathrm{IBA}$ proved to be superior in terms of maximum floral diameter of "Basanthi", whereas the maximal flower fresh weight was recorded in the plants of "Narangi" receiving foliar application of $800 \mathrm{mg} \cdot \mathrm{L}^{-1} \mathrm{GA}_{3}$. Regardless of the concentration, OA significantly improved flower dry weight, total phenolic contents, total flavonoid contents and reducing power ability of "Narangi". The plants of "Basanthi" treated with $100 \mathrm{mg} \cdot \mathrm{L}^{-1}$ IBA exhibited maximum DPPH free radical scavenging activity. The highest dose of the PGRs viz. $800 \mathrm{mg} \cdot \mathrm{L}^{-1}$ was applied to evaluate its lethal effects on plant health. The results proved that this dose was not harmful for plants, indicating the African marigold as a hardy plant. Overall, PGRs 
at specific concentrations may be used as an effective exogenous application strategy to improve the flowering and antioxidant capacity of marigold flowers.

Author Contributions: Conceptualization, S.S., M.M.A. and S.N.; methodology, S.S. and M.U.; statistical analysis, M.M.A. and A.F.Y.; data curation, M.M.A.; writing-original draft preparation, S.S. and M.M.A.; writing-review and editing, M.U.H., M.A., S.G. and S.N. All authors have read and agreed to the published version of the manuscript.

Funding: This research received no external funding.

Institutional Review Board Statement: Not applicable.

Informed Consent Statement: Not applicable.

Acknowledgments: Authors would like to thank all field technicians at Institute of Horticultural Sciences, University of Agriculture, Faisalabad.

Conflicts of Interest: The authors declare no conflict of interest.

\section{References}

1. Bussmann, R.W.; Batsatsashvili, K.; Kikvidze, Z.; Paniagua-Zambrana, N.Y.; Khutsishvili, M.; Maisaia, I.; Sikharulidze, S.; Tchelidze, D. Tagetes erecta L. Asteraceae. In Ethnobotany of the Mountain Regions of Far Eastern Europe; Springer: Berlin/Heidelberg, Germany, 2020; pp. 1-5.

2. Parađiković, N.; Teklić, T.; Zeljković, S.; Lisjak, M.; Špoljarević, M. Biostimulants research in some horticultural plant species-A review. Food Energy Secur. 2019, 8, e00162. [CrossRef]

3. Choudhary, M.; Beniwal, B.S.; Kumari, A. Characterization of marigold genotypes using morphological characters. Res. Crop. 2014, 15, 839. [CrossRef]

4. Afzal, I.; Rahim, A.; Qasim, M.; Younis, A.; Nawaz, A.; Bakhtavar, M.A. inducing salt tolerance in french marigold (Tagetes patula) through seed priming. Acta Sci. Pol. Hortorum Cultus 2017, 16, 109-118. [CrossRef]

5. Singh, R.; Meena, M.L.; Verma, S.; Vilas, R.; Saurabh, V.; Mauriya, S.K.; Maurya, R.; Kumar, M. A review on performance of gibberellic acid on African marigold. J. Pharmacogn. Phytochem. 2019, 8, 43-46.

6. Riaz, A.; Younis, A.; Taj, A.R.; Karim, A.; Tariq, U.; Munir, S.; Riaz, S. Effect of drought stress on growth and flowering of marigold (Tagetes erecta L.). Pak. J. Bot. 2013, 45, 123-131.

7. Jowkar, M.; Salehi, H. Effects of different preservative solutions on the vase life of cut tuberose flowers at usual home conditions. Acta Hortic. 2005, 411-416. [CrossRef]

8. Gautam, S.K.; Sen, N.L.; Jain, M.C.; Dashora, L.K. Effect of plant growth regulators on growth, flowering and yield of chrysanthemum (Chrysanthemum morifolium Ram.) cv. 'Nilima. Orrisa J. Hortic. 2006, 34, 36-40.

9. Sharma, L.; Collis, J.P. Effect OF plant growth regulators on growth and flower yield of petunia (Petunia hybrida L.). J. Plant. Dev. Sci. 2017, 9, 513-514.

10. Murugan, V.T.; Manivannan, K.; Nanthakumar, S. Studies on the effect of plant growth regulators on growth, flowering and xanthophyll content of African marigold (Tagetes erecta L.). Int. J. Curr. Microbiol. Appl. Sci. 2020, 9, 3767-3771. [CrossRef]

11. Shahzad Akhtar, M.; Aslam Khan, M.; Riaz, A.; Younis, A. Response of different rose species to different root promoting hormones. Pak. J. Agric. Res. 2002, 39, 297-299.

12. Aziz, S.; Younis, A.; Jaskani, M.; Ahmad, R. Effect of PGRs on antioxidant activity and phytochemical in delay senescence of lily cut flowers. Agronomy 2020, 10, 1704. [CrossRef]

13. Pawar, A.; Saraladevi, D.; Kannan, M.; SabirAhamed, A. Effect of micronutrients and plant growth regulators on growth, flowering and yield attributes of marigold (Tagetes erecta L.). Madras Agric. J. 2019, 106, 4-6. [CrossRef]

14. Ali, M.M.; Yousef, A.F.; Li, B.; Chen, F. Effect of environmental factors on growth and development of fruits. Trop. Plant Biol. 2021, 1-13. [CrossRef]

15. Ali, M.M.; Anwar, R.; Malik, A.U.; Khan, A.S.; Ahmad, S.; Hussain, Z.; Hasan, M.U.; Nasir, M.; Chen, F. Plant growth and fruit quality response of strawberry is improved after exogenous application of 24-epibrassinolide. J. Plant Growth Regul. 2021, 40, 1-14. [CrossRef]

16. Ibrahim, M.; Agarwal, M.; Yang, J.O.; Abdulhussein, M.; Du, X.; Hardy, G.; Ren, Y. Plant growth regulators improve the production of volatile organic compounds in two rose varieties. Plants 2019, 8, 35. [CrossRef]

17. Ali, S.; Charles, T.; Glick, B. Delay of flower senescence by bacterial endophytes expressing 1-aminocyclopropane-1-carboxylate deaminase. J. Appl. Microbiol. 2012, 113, 1139-1144. [CrossRef]

18. Bhattacharyya, S.; Datta, S.; Mallick, B.; Dhar, P.; Ghosh, S. Lutein content and in vitro antioxidant activity of different cultivars of indian marigold flower (Tagetes patula L.) extracts. J. Agric. Food Chem. 2010, 58, 8259-8264. [CrossRef]

19. Vatai, T.; Škerget, M.; Knez, Ž. Extraction of phenolic compounds from elder berry and different grape marc varieties using organic solvents and/or supercritical carbon dioxide. J. Food Eng. 2009, 90, 246-254. [CrossRef] 
20. Li, W.; Gao, Y.; Zhao, J.; Wang, Q. Phenolic, flavonoid, and lutein ester content and antioxidant activity of 11 cultivars of chinese marigold. J. Agric. Food Chem. 2007, 55, 8478-8484. [CrossRef] [PubMed]

21. Ramadan, M.F.; Kroh, L.W.; Mörsel, J.-T. Radical scavenging activity of black cumin (Nigella sativa L.), coriander (Coriandrum sativum L.), and niger (Guizotia abyssinica Cass.) crude seed oils and oil fractions. J. Agric. Food Chem. 2003, 51, 6961-6969. [CrossRef] [PubMed]

22. Habila, J.D.; Bello, I.A.; Dzikwi, A.A.; Musa, H.; Abubakar, N. Total phenolics and antioxidant activity of Tridax procumbens Linn. Afr. J. Pharm. Pharmacol. 2010, 4, 123-126. [CrossRef]

23. Kumar, M.; Singh, A.K.; Kumar, A. Effect of plant growth regulators on flowering and yield attributes of African marigold (Tagetes Erecta L.). Plant. Arch. 2014, 14, 363-365.

24. Mitchell, J.W.; Stewart, W.S. Comparison of growth responses induced in plants by naphthalene acetamide and naphthalene acetic acid. Bot. Gaz. 1939, 101, 410-427. [CrossRef]

25. Dhumal, S.; Kaur, M.; Dalave, P.; Garande, V.K.; Pawar, R.D.; Ambad, S.S. Regulation of growth and flowering in tuberose with application of bio-regulators. Int. J. Curr. Microbiol. Appl. Sci. 2018, 7, 1622-1626. [CrossRef]

26. Shinde, K.H.; Parekh, N.S.; Upadhyay, N.V.; Patel, H.C. Investigation of different levels of gibberellic acid (GA3) and pinching treatments on growth, flowering and yield of chrysanthemum (Chrysanthemum morifolium Ramat.) cv. "IIHR-6" under middle Gujarat conditions. Asian J. Hortic. 2010, 5, 416-419.

27. Shivaprakash, B.; Hugar, A.; Kurubar, A.; Vasudevan, S.; Husain, S. Studies on impact of bio-fertilizers and GA 3 on growth and flower yield of marigold (Tagetes erecta L.) cv. Asian J. Hortic. 2011, 6, 406-411.

28. Pushkar, N.C.; Singh, A.K. Effect of pinching and growth retardants on flowering and yield of African marigold (Tagetes erecta L.) var. Pusa Narangi Gainda. Int. J. Hortic. 2012, 10, 109-111. [CrossRef]

29. Kumar, R.; Ram, M.; Gaur, G.S. Effect of GA3 and ethrel on growth and flowering of African marigold cv. Pusa Narangi Gainda. Indian J. Hortic. 2010, 67, 362-366.

30. Kumar, N.; Kumar, J.; Singh, J.; Kaushik, H.; Singh, R. Effect of GA3 and Azotobacter on growth and flowering in African marigold (Tagetes erecta L.) cv. Pusa Narangi Gainda. Asian J. Hortic. 2016, 11, 382-386. [CrossRef]

31. Karlidag, H.; Yildirim, E.; Turan, M. Salicylic acid ameliorates the adverse effect of salt stress on strawberry. Sci. Agric. 2009, 66, 180-187. [CrossRef]

32. Alirezaie, H.B.; Neamati, H. Impact of exogenous salicylic acid on growth and ornamental characteristics of calendula (Calendula officinalis L.) under salinity stress. J. Stress Physiol. Biochem. 2012, 8, 258-267.

33. Kumar, A.; Kumar, J.; Mohan, B.; Singh, J.; Rajbeer; Ram, N. Effect of plant growth regulators on growth, flowering and yield of African marigold (Tagetes erecta L.) cv. Pusa Narangi Gainda. Asian J. Hortic. 2011, 6, 418-422.

34. Kaushik, S.; Shukla, N. Effect of IBA and NAA and their combination on the shooting of stem cuttings of African marigold (Tagetes erecta L.) cv. Pusa Narangi Gainda. Int. J. Chem. Stud. 2020, 8, 1800-1802. [CrossRef]

35. Ullah, Z.; Abbas, S.J.; Naeem, N.; Lutfullah, G.; Malik, T.; Khan, M.A.U.; Khan, I. Effect of indolebutyric acid (IBA) and naphthaleneacetic acid (NAA) plant growth regulaters on Mari gold (Tagetes erecta L.). Afr. J. Agric. Res. 2013, 8, 4015-4019.

36. Rezazadeh, A.; Harkess, R.L.; Bi, G. Effect of plant growth regulators on growth and flowering of potted red firespike. HortTechnology 2016, 26, 6-11. [CrossRef]

37. Morshed, M.N.; Deb, H.; Azad, S.A.; Sultana, M.Z.; Ashaduzzaman; Guha, A.K. Aqueous and solvent extraction of natural colorants from Tagetes Erecta L., Lawsonia Inermis, Rosa L for coloration of cellulosic substrates. Am. J. Polym. Sci. Technol. 2016, 2, 34-39. [CrossRef]

38. Waterland, N.L.; Campbell, C.A.; Finer, J.; Jones, M.L. abscisic acid application enhances drought stress tolerance in bedding plants. HortScience 2010, 45, 409-413. [CrossRef]

39. Hunt, L.; Lerner, F.; Ziegler, M. NAD—new roles in signalling and gene regulation in plants. New Phytol. 2004, 163, 31-44. [CrossRef] [PubMed]

40. Narute, T.T.; Parulekar, Y.R.; Narute, T.K. Effect of plant growth regulators on yield and yield attributing character of marigold cv. Calcutta Marigold under Konkan conditions. Int. J. Curr. Microbiol. Appl. Sci. 2020, 9, 3998-4005. [CrossRef]

41. Basit, A. Salicylic acid an emerging growth and flower inducing hormone in marigold (Tagetes sp. L.). Pure Appl. Biol. 2018, 7. [CrossRef]

42. Hashemabadi, D.; Zaredost, F.; Ziyabari, M.B.; Zarchini, M.; Kaviani, B.; Solimandarabi, M.J.; Torkashvand, A.M.; Zarchini, S. Influence of phosphate bio-fertilizer on quantity and quality features of marigold (Tagetes erecta L.). Aust. J. Crop. Sci. 2012, 6, 1101-1109.

43. Liao, W.; Huang, G.; Yu, J.; Zhang, M.; Shi, X. Nitric oxide and hydrogen peroxide are involved in indole-3-butyric acid-induced adventitious root development in marigold. J. Hortic. Sci. Biotechnol. 2011, 86, 159-165. [CrossRef]

44. Haq, S.U.; Shah, S.T.; Khan, N.; Khan, A.; Ahmad, N.; Ali, M.; Gul, G.; Rahman, S.; Afzaal, M.; Ullah, S.; et al. Growth and flower quality production of marigold (Tagetes erecta L.) response to phosphorous fertilization. Pure Appl. Biol. 2016, 5, 957-962. [CrossRef]

45. Asrar, A.-W.A.; Elhindi, K.M. Alleviation of drought stress of marigold (Tagetes erecta) plants by using arbuscular mycorrhizal fungi. Saudi J. Biol. Sci. 2011, 18, 93-98. [CrossRef] [PubMed]

46. Kumar, R.; Kumar, A.; Kumar, A. Effect of nutrients on growth, flowering and yield of African marigold (Tagetes erecta L.) cv. Pusa Narangi Gainda. Int. J. Curr. Microbiol. Appl. Sci. 2018, 7, 205-209. [CrossRef] 
47. Rathore, I.; Mishra, A.; Moond, S.K.; Bhatnagar, P. Studies on effect of pinching and plant bioregulators on growth and flowering of marigold (Tagetes erecta L.) cv. Pusa Basanti Gainda. Progress. Hortic. 2011, 43, 52-55.

48. Khobragade, R.K.; Bisen, S.; Thakur, R.S. Effect of planting distance and pinching on growth, flowering and yield of China aster (Callistephus chinensis.) cv. Poornima. Indian J. Agric. Sci. 2012, 82, 334-339.

49. Sailaja, S.M.; Panchbhai, D.M.; Suneetha, K. Response of China aster varieties to pinching for growth, yield and quality. HortFlora Res. Spectr. 2013, 2, 366-368.

50. Pacheco, A.C.; Cabral, S.; Sabrina, É. Salicylic acid-induced changes to growth, flowering and flavonoids production in marigold plants. J. Med. Plants Res. 2013, 7, 3158-3163. [CrossRef]

51. Choudhary, A.; Mishra, A.; Bola, P.K.; Moond, S.K.; Dhayal, M. Effect of foliar application of zinc and salicylic acid on growth, flowering and chemical constitute of African marigold cv. pusa narangi gainda (Targets erecta L.). J. Appl. Nat. Sci. 2016, 8, 1467-1470. [CrossRef]

52. Pal, S. Role of plant growth regulators in floriculture: An overview. J. Pharmacogn. Phytochem. 2019, 8, 789-796.

53. Khanvilkar, M.; Kokate, K.D.; Mahalle, S. Performance of African marigold (Tagetes erecta) in North Konkan coastal zone of Maharashtra. J. Maharashtra Agric. Univ. 2003, 28, 333-334.

54. Rao, C.; Goud, P.V.; Reddy, K.M.; Padmaja, G. Screening of African marigold (Tagetes erecta L.) cultivars for flower yield and carotenoid pigments. Indian J. Hortic. 2005, 62, 276-279.

55. Jung, C.; Maeder, V.; Funk, F.; Frey, B.; Sticher, H.; Frossard, E. Release of phenols from Lupinus albus L. roots exposed to Cu and their possible role in Cu detoxification. Plant Soil 2003, 252, 301-312. [CrossRef]

56. Yoon, H.K.; Muhammad, H.; Abdul, L.K.; Na Chae, I.; Sang, M.K.; Hyun, H.H.; Jung, L.I. Exogenous application of plant growth regulators increased the total flavonoid content in Taraxacum officinale Wigg. Afr. J. Biotechnol. 2009, 8, 5727-5736. [CrossRef]

57. Zeb, A.; Ullah, F.; Gul, S.L.; Khan, M.; Zainub, B.; Khan, M.N. Influence of salicylic acid on growth and flowering of zinnia. Sci. Int. 2017, 29, 1329-1335.

58. Karalija, E.; Neimarlija, D.; Cakar, J.; Paric, A. Elicitation of biomass and secondary metabolite production, antioxidative and antimicrobial potential of basil and oregano induced by BA and IBA application. Eur. J. Med. Plants 2016, 14, 1-11. [CrossRef]

59. Karalija, E.; Parić, A. The effect of BA and IBA on the secondary metabolite production by shoot culture of Thymus vulgaris L. Biol. Nyssana 2011, 2, 29-35.

60. Siatka, T.; Kašparová, M. Seasonal variation in total phenolic and flavonoid contents and dpph scavenging activity of Bellis perennis L. flowers. Molecules 2010, 15, 9450-9461. [CrossRef]

61. Rahman, M.; Islam, B.; Biswas, M.; Alam, A.H.M.K. In vitro antioxidant and free radical scavenging activity of different parts of Tabebuia pallida growing in Bangladesh. BMC Res. Notes 2015, 8, 621. [CrossRef] [PubMed]

62. Gong, Y.; Liu, X.; He, W.-H.; Xu, H.-G.; Yuan, F.; Gao, Y.-X. Investigation into the antioxidant activity and chemical composition of alcoholic extracts from defatted marigold (Tagetes erecta L.) residue. Fitoterapia 2012, 83, 481-489. [CrossRef] [PubMed]

63. Bukhari, S.B.; Bhanger, M.I.; Memon, S. Antioxidative activity of extracts from fenugreek seeds (trigonella foenum-graecum). Pak. J. Anal. Environ. Chem. 2008, 9, 78-83.

64. Ćetković, G.S.; Djilas, S.M.; Čanadanović-Brunet, J.M.; Tumbas, V.T. Antioxidant properties of marigold extracts. Food Res. Int. 2004, 37, 643-650. [CrossRef] 